Portland State University

PDXScholar

\title{
Sounding the Atmosphere during the First World War: American Meteorological Practice in the Signal Corps Meteorological Service, 1917-1937
}

Ian M. Rollins

Portland State University

Follow this and additional works at: https://pdxscholar.library.pdx.edu/honorstheses

Let us know how access to this document benefits you.

\section{Recommended Citation}

Rollins, Ian M., "Sounding the Atmosphere during the First World War: American Meteorological Practice in the Signal Corps Meteorological Service, 1917-1937" (2017). University Honors Theses. Paper 405. https://doi.org/10.15760/honors.401

This Thesis is brought to you for free and open access. It has been accepted for inclusion in University Honors Theses by an authorized administrator of PDXScholar. Please contact us if we can make this document more accessible: pdxscholar@pdx.edu. 
SOUNDING THE ATMOSPHERE DURING THE FIRST WORLD WAR:

\title{
AMERICAN METEOROLOGICAL PRACTICE
}

IN THE SIGNAL CORPS METEOROLOGICAL SERVICE, 1917-1937

by

Ian M. Rollins

An undergraduate honors thesis submitted in partial fulfillment of the requirements for the degree of

\author{
Bachelor of Arts \\ in \\ University Honors \\ and \\ History
}

Thesis Advisor

Richard Beyler

Portland State University

2017 


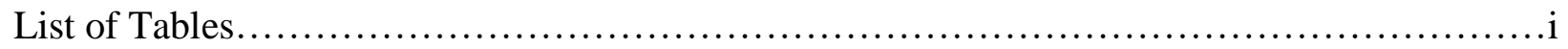

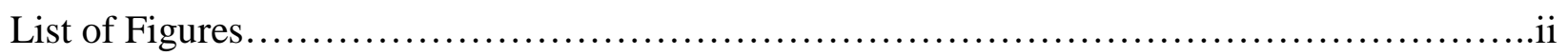

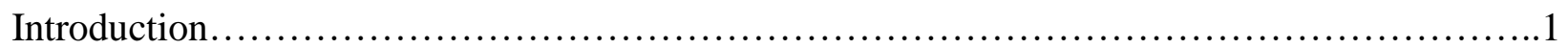

A Brief History of Meteorology in America............................................... 2

A Historiography of American Meteorology and the First World War...................5

The Signal Corps Meteorological Service: Wartime Activities............................10

Formation of the Meteorological Service.....................................11

Organization of the Meteorological Service....................................13

Military Applications of Meteorological Support.....................................24

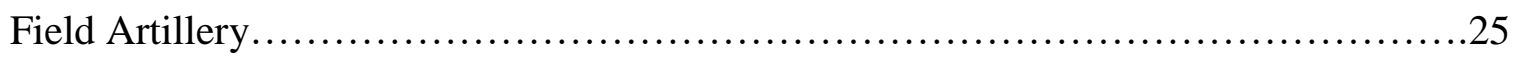

Sound Ranging........................................................ 27

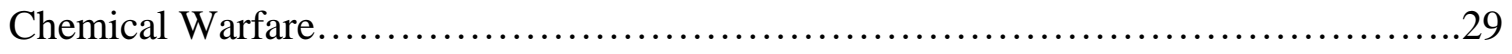

Aerial Operations........................................................... 31

Army Corps of Engineers................................................... 33

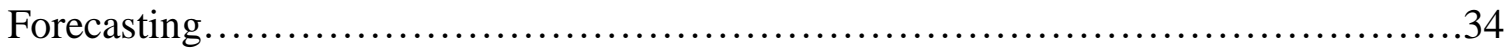

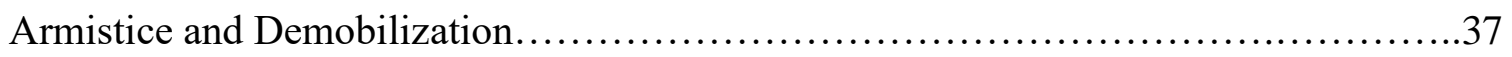

The Signal Corps Meteorological Service: Interwar Conflicts and Dissolution..................38

New Directions and Developments......................................... 38

Failures, Shortcomings, and Dissolution................................... 45

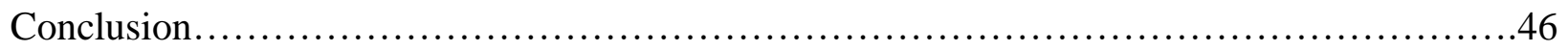

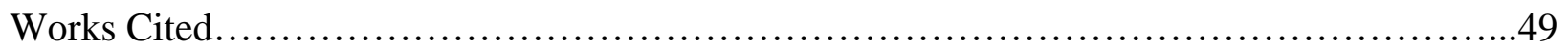




\section{List of Tables}

Table 1 - list of upper-air sounding methods considered for military use in $1917 \ldots \ldots \ldots 18$ 


\section{List of Figures}

Figure 1 - An idealized image of a typical Meteorological Service observation station....14

Figure 2 - Detail of the contents of an instrument shelter.......................... 14

Figure 3 - Image showing the variation in wind conditions at low elevations.............17

Figure 4 - Pilot balloon sounding plotting board, "ML 55" $\ldots \ldots \ldots \ldots \ldots \ldots \ldots \ldots \ldots . \ldots 20$

Figure 5 - Map of the Meteorological Service's observations station network in France...23

Figure 6 - Diagram of the acoustic principles that facilitated sound-ranging..............28

Figure 7 - Diagram showing the ideal structure of a front-line sound ranging station......28 


\section{Introduction}

The First World War (1914-1918) had become the most modern and costliest conflict in the history of Europe and its colonies at the time of the armistice in 1918. New and improved weapons were coupled with an intense nationalistic mobilization of all resources available to the state. This combination forced all modern militaries to push the limits of what was conventionally considered relevant or useful to a war effort in order to gain the advantage over their rival. For instance, with a degree of research and development, industrialized chemical production processes could be altered to produce mass quantities of poison gas, the air could be used as a platform for reconnaissance or bombing, and the weather could be monitored and forecasted to aid in the efficient operation of an entire war machine. While the spread of air combat operations and the use of chemicals in warfare are well studied threads in the history of the First World War, meteorological science and its practice on this modernized battlefield has largely been neglected by modern scholars.

The United States joined the war in April 1917 and many of its academic, government, and military institutions experienced the destructive and formative effects of the war. The creation of the Signal Corps Meteorological Service is an example of a formative effect of the war. Throughout the conflict, meteorological science was strained to the limit of its predictive capability while the hardware and techniques associated with the procedural gathering of weather data were also strained, expanded, and solidified into general practice.

This thesis will describe the formation and operation of the Signal Corps Meteorological Service during and after the First World War in order to highlight both the applied capabilities and limitations of meteorological practice during the first quarter of the twentieth century. I 
intend to show that the First World War facilitated the expansion of a standardized meteorological practice and solidified the relevance of meteorology in both military and domestic affairs. The majority of this thesis will be devoted to studying the formation of the Meteorological Service, the structure and organization of a typical observation station, and the multitude of military services that required meteorological support. Before this, I will summarize the practice of meteorology in America up to 1914 before examining a selection of scholarship that studies meteorology in America as well as meteorology in the First World War. In my later sections I will examine the transition of the Meteorological Service from its overseas wartime operations to its domestic peacetime role by analyzing a few articles of a series that advertised the recent work of the Service. Finally, I will describe the dissolution and absorption of the Service into the Air Corps in 1937 after nearly two decades of chronic underfunding. I intend to show that the wartime work of the Meteorological Service utilized and built upon established meteorological practice and that the First World War brought more attention (both military and civilian) to meteorology than the subject had ever seen in the past.

\section{A Brief History of Meteorology in America}

Meteorology in the eighteenth and early-nineteenth centuries was mostly a practice of gathering measurements of surface atmospheric conditions in order to generate broad hypotheses that described weather phenomena. At this time meteorology was largely studied by "amateurs." Modern scholarship of the history of science utilizes the concept of the "amateur" scientist to describe an informally educated and self-funded individual who contributed to various fields of 
science before professionalization had begun to formalize the contribution process. ${ }^{1}$ In the context of the history of meteorology in America, amateurs included not only wealthy "gentleman" scientists but also non-elites equipped with the instruments necessary to take regular weather measurements. ${ }^{2}$ Thomas Jefferson and James Madison are examples of the former group who, in 1778, conducted a meteorological experiment by coordinating their observations of pressure, temperature, and winds in order to compare differences in weather between two different places. ${ }^{3}$ Amateur observers like Jefferson and Madison compiled personal weather journals - records of observations taken at regular intervals over an extended period of time. Ideally, the data in these weather journals could be collected and studied by experienced amateurs to shed light on early meteorological problems such as the link between local climate and disease or the wind pattern around the eye of a storm. Often discrepancies in the calibration and design of measuring instruments made comparing readings impossible while the traditional postal service made the exchange of data only useful for compiling climatological statistics. In short, meteorology was an "art" that consisted of sporadic and unstandardized observations coupled with generalized associations until roughly the second half of the nineteenth century.

During the second half of the century, non-elite amateurs cooperated with the Smithsonian meteorological organization by faithfully taking weather observations in remote locations. Consistency, attention to detail, and procedural discipline were the prime requisites for these observers as opposed to wealth or specialized education. This distinction in qualification

\footnotetext{
${ }^{1}$ Conevery B. Valencius et al., "Science in Early America: Print Culture and the Sciences of Territoriality," Journal of the Early Republic 36 (2016): 73-74.

2 James Rodger Fleming, Meteorology in America, 1800-1870 (Baltimore: Johns Hopkins University Press, 1990), 81, 86-87; Valencius, "Science in Early America," 76.

${ }^{3}$ Fleming, Meteorology in America, 9-10; Charles Bates and John Fuller, America's Weather Warriors, 18141985 (College Station: Texas A\&M University Press, 1986), 3-4.
} 
enabled relatively less privileged individuals to share the duty of gathering meteorological data for use in forecasting and the study of weather phenomenon. Telegraph officers were prime candidates for observation responsibility because they were already grounded at one location and were able to properly house instruments and record weather data at regular hours. More importantly, a telegraph officer would have direct access to the most useful tool for mass observation and forecasting: the telegraph. The availability of new technologies like the telegraph as well as the creation of a government organized observation network brought the status of meteorology from an amateur hobby to a "barely reputable" science with a small presence in the American university. Eventually, these non-elite amateurs were phased out as meteorological organizations became federalized in the 1870s and as the tasks required of contributors became increasingly complex.

The government weather forecasting and research organization that is known today as the National Weather Service was originally founded in 1870 as a branch of the U.S. Army Signal Corps. By 1891, the Signal Corps shed its weather responsibilities when the Weather Bureau was formed under the Department of Agriculture. ${ }^{5}$ The Signal Corps and later the domestic Weather Bureau operated over a hundred observation stations equipped with standardized measuring equipment and a telegraph. These tools helped facilitate their primary duty as a meteorological organization: forecasting. ${ }^{6}$ Forecasts were issued twice daily from the central Weather Bureau

\footnotetext{
${ }^{4}$ Kristine Harper, Weather and Climate: Decade by Decade (New York: Facts On File, 2007), xix. See also Fleming, Meteorology in America, 170-74; Harper, Weather and Climate, 1, 7-10.

${ }^{5}$ During the emergency mobilization of the First World War, the Signal Corps would once again take on meteorological support responsibilities for the military and operated in tandem with the Weather Bureau in the United States.

${ }^{6}$ Bates and Fuller, Weather Warriors, 9-14; Patrick Hughes, A Century of Weather Service: A History of the Birth and Growth of the National Weather Service, 1870-1970 (New York: Gordon and Breach, Science Publishers, 1970), 1-73; Donald Whitnah, A History of the United States Weather Bureau (Urbana: University of Illinois Press, 1961).
} 
office in Washington D.C. and were meant to predict general weather conditions for the coming 48 hours in the vicinity of the major signal offices across the United States. Forecasts were made by one man, the chief forecaster, who processed and interpreted data as it came in via telegraph from the nationwide observation network and was plotted on various synoptic charts of weather conditions. ${ }^{7}$ This forecaster's ability to read incoming data and issue an accurate forecast was fine-tuned from years of exposure to climatological data and experience with forecasting procedure. Therefore, forecasting - the main application of meteorological science-could only be performed by a handful of highly experienced men with an innate sense of weather behavior and the ability to infer patterns in large sets of data. In short, a good forecaster was simply "born" and could not be "made." ${ }^{\prime 8}$ From the 1870s through the 1920 s this forecasting structure remained unaltered — save for the incorporation of larger amounts and newer kinds of atmospheric data. Although the limits of this procedure were known to meteorologists before 1914, the emergency presented by the First World War and the expansion of meteorology's military application during the conflict highlighted the need for an academic infrastructure for both training qualified personnel to work for the weather services and for increasing the accuracy of forecasts.

\section{A Historiography of American Meteorology and the First World War}

Data gathering capabilities increased steadily into the twentieth century, but the empirical methods by which this data was applied had changed little. By the turn of the last century of growth and wider application of the science, meteorology had begun to reach its ceiling of

\footnotetext{
${ }^{7}$ Hughes, Weather Service, 26, 63.

${ }^{8}$ Hughes, Weather Service, 86.
} 
accuracy which thereby limited the usefulness of empirical meteorological practice. Kristine Harper has referred to this era of meteorological science after 1900 and before the Second World War as "stagnant" in order to highlight the slowing of meteorology's growth as a physical science in the United States before its launch into the scientific mainstream during the 1950 s. $^{9}$ Limits to meteorology's growth during its "stagnant" period included its weak presence in the American university, a scarcity of patronage, and a lack of theoretical research. By 1919, a survey conducted by the Department of Education asked 600 universities with an average science curriculum about their course offerings in meteorology. Only 70 universities replied that they offered meteorology as a separate course while 83 lumped the subject into other courses (often geography or physics). ${ }^{10}$ This study shows that students in higher education had few options for pursuing the study of meteorology and that the pool of academically trained meteorologists was correspondingly shallow. For that matter, approximately 922 doctoral degrees were awarded from 1919-1923, roughly 600, 200, 100, and 20 were awarded in chemistry, botany and physics, geology, and astronomy respectively with only two awarded in meteorology. ${ }^{11}$ These statistics were both compiled after the First World War where meteorological support of both military and commercial operations was proven to be necessary.

This lack of academic presence was further compounded by a shortage of funding in most American meteorological services during this period. For instance, funding for Britain's meteorological services was increased by $800 \%$ during the First World War whereas American

\footnotetext{
${ }^{9}$ Kristine Harper, Weather by the Numbers: The Genesis of Modern Meteorology (Cambridge: MIT Press, 2008), 11.

${ }^{10}$ Harper, Numbers, 51-52, Charles Brooks, "General Extent of Collegiate Instruction in Meteorology and Climatology in the United States," Monthly Weather Review 47 (1919): 169-70.

${ }^{11}$ Harper, Numbers, 49.
} 
spending was only increased by $40 \%$ between 1908 and $1919 .{ }^{12}$ Specifically, the Weather Bureau was only allotted \$2 million to run over 200 stations in 1921 while the Meteorological Service was only allotted $\$ 67,400$ in 1924 (up from $\$ 40,000$ in 1923). This can be compared to the Office of (agricultural) Experiment Stations which was allotted \$250,000 to manage five research stations. ${ }^{13}$ The Weather Bureau and Meteorological Service were hard pressed to perform their basic meteorological support duties because of their low budgets. Therefore, they could not afford to adequately expand their services or develop their own academic training programs to meet the increasing demand for commercial meteorological support during the interwar period.

These academic and financial troubles also limited the pursuit of theoretical research into understanding the origins of meteorological phenomenon during this period. Most meteorological work done by government organizations at this time was centered on the empirical pursuits of data collection and weather forecasting. The accuracy and range of forecasts could only be marginally improved with greater amounts of data and refinements to the myriad of rules that described meteorological phenomenon. As early as 1904, Norwegian physicist Vilhelm Bjerknes sought to apply mathematics and fluid dynamics to meteorology to begin to solve this impasse. ${ }^{14}$ Unfortunately, the lack of funds and academic foundation caused his work to go largely unnoticed and uninvestigated in the United States until the 1930s. After

\footnotetext{
${ }^{12}$ Kristine Harper, "Meteorology's Struggle for Professional Recognition in the USA (1900-1950)," Annals of Science 63 (2006): 187.

${ }^{13}$ John Fuller, Thor's Legions: Weather Support to the U.S. Air Force and Army: 1937-1987 (Boston: American Meteorological Society, 1990), 17.

${ }^{14}$ Harper, Weather and Climate, 7-10, 16-17. This required Bjerknes to convince both physicists and meteorologists to work together - a difficult task considering physicists tended to regard meteorology as a matter of guessing rather than science, see Harper, "Meteorology's Struggle," 181; Robert Friedman, Appropriating the Weather: Vilhelm Bjerknes and the Construction of a Modern Meteorology (Ithaca: Cornell University Press, 1989), 33-59.
} 
the Second World War and decades of slow growth, the introduction of numerous technologies (including radar and electronic computers) and the necessary scaling up of government and military meteorology organizations facilitated the establishment of meteorology as an academic and theoretically rigid science in the United States.

At the heart of this "stagnant" period was the First World War. The armed forces of the Entente and Central Powers realized early in the war that meteorology needed systematic observation because new military technologies - namely long-range artillery, gas, and rigid/nonrigid aircraft—required meteorological data in order to be effective. The United States was no exception and by the summer of 1918 the American Expeditionary Force (A.E.F.) had mobilized a meteorological service to support almost every branch of the American armed forces. Most scholars of meteorology in twentieth century America who summarize the "stagnant" period give a brief mention of the Signal Corps Meteorological Service.

Philip Flammer wrote the most complete study to date of the Meteorological Service in his 1958 master's thesis. ${ }^{15}$ His work provides a basic narrative of the Meteorological Service from its founding in 1917 to its dissolution in 1937. It is substantially based on archival materials - including the annual reports of the Chief Signal Officer that remain unpublished today-personal interviews, and articles from the Monthly Weather Review. His work has also stood for over half a century without being substantially contributed to or challenged by more recent scholarship with access to new source material. Although scholars can utilize Flammer's work to acquire an idea of the purpose of the Meteorological Service as well as some of the limitations it faced during the inter-war period, there is little indication of how the war or the

\footnotetext{
${ }^{15}$ Philip Flammer, "Meteorology in the United States Army, 1917-1935” (MA thesis, George Washington University, 1958).
} 
Service contributed to the science of meteorology. The work of this paper is meant to address this shortcoming.

Most scholars who wish to verify their section on the First World War's effect on meteorology tend to cite Flammer. For example, Kristine Harper, John Fuller, Charles Bates, Rebecca Raines, Robert Friedman, and Frederik Nebeker all provide brief summaries of this subject before moving on to the main purpose of their works. ${ }^{16}$ These summaries range in length from the nine page treatment in America's Weather Warriors to an extended paragraph such as that found in the Signal Corps' official series of branch histories. ${ }^{17}$ The content of these summaries usually include a list of the military's needs for meteorological support during the First World War followed by the observation that the Meteorological Service's rapid demobilization after the armistice limited the continuation of their wartime work. Overall, these summaries tend to look at the First World War and the Meteorological Service as an example of the inertia of meteorological sciences during the "stagnant" period before moving on to the Second World War where more significant events occurred.

I intend to push back against this summarization trend by building on Flammer's original record of the Meteorological Service via a detailed description of the Service's methodological data gathering duties as well as its interaction with the armed forces. These details will show how the wartime work of the Meteorological Service simultaneously emphasized the limitations

\footnotetext{
${ }^{16}$ Kristine Harper, "Boundaries of Research: Civilian Leadership, Military Funding, and the International Network Surrounding the Development of Numerical Weather Prediction in the United States" (PhD diss., Oregon State University, 2003); Harper, “Meteorology's Struggle," 179-99; Harper, Numbers; Harper, Weather and Climate; Fuller, Thor's Legions; Bates and Fuller, Weather Warriors; Rebecca Raines, Getting the Message Through: A Branch History of the U.S. Army Signal Corps (Washington: Center of Military History United States Army, 1996); Friedman, Appropriating the Weather; Frederik Nebeker, Calculating the Weather: Meteorology in the 20 $0^{\text {th }}$ Century (San Diego: Academic Press, 1995).

${ }^{17}$ Bates and Fuller, Weather Warriors, 15-23; Raines, Message, 190.
} 
of applied meteorology and helped strengthen meteorology's relevance to a wider audience. Although the United States was only mobilized for the First World War for around a year and a half, the effect of the war on the science of meteorology was significant and must be studied to shed light on this field of study prior to the introduction of new data gathering and processing technologies after the Second World War.

\section{The Signal Corps Meteorological Service: Wartime Activities}

Although the United States was not directly involved in First World War until 1917, most citizens could follow its passage by reading articles in their favorite magazines and journals. Readers of Robert DeCourcy Ward's series of articles in the Journal of Geography were regularly updated about the effects of weather on the war across its fronts. The third installation of this series_-published in March, 1915-includes a reference to German meteorological observers who moved into Belgium to issue local weather forecasts. ${ }^{18}$ In the fifth issuepublished in November, 1915-Ward describes the German meteorology observation station at Uccle and its use of pilot balloons to gather upper air wind data. ${ }^{19}$ These two references show that the German military was at least attempting to provide sophisticated meteorological support to its armed forces by 1915 . None of the articles of Ward's 1914-1918 series mention the structure, purpose, or existence of the Allied meteorological services that functioned at this time (perhaps a measure of censorship was present), but a careful reader could easily surmise that the

\footnotetext{
${ }^{18}$ Robert Ward, “The European Winter and the War,” Journal of Geography 13 (1915): 213.

${ }^{19}$ Robert Ward, "The Weather Factor in the Great War: III," Journal of Geography 14 (1915): 74-75. By the end of the war, Germany had meteorological support integrated into each Army in the field. An Army Meteorological Station was located at each headquarters that issued two forecasts daily and worked in close conjunction with gas officers and aircraft units. At the divisional level there were observations stations with multiple forward wind observation stations, see The German Army Handbook of 1918 (London: Frontline Books, 2008 ), 125.
} 
major combatants understood and responded to the necessity of meteorological support in the First World War.

\section{Formation of the Meteorological Service}

The United States committed the American Expeditionary Force (A.E.F.) to fight the First World War in France on April 6, 1917. By June, the American government was prepared to begin building up a complete army in Europe. This task required an expansion in nearly every branch of the armed forces, including the creation of a dedicated meteorological service. General E. Russel, the chief signal officer of the A.E.F., confirmed the need for this service in June 1917 when he registered a request for a meteorological support unit. ${ }^{20}$ Since there was no pre-war military meteorology service, one would have to be formed from scratch as soon as possible.

The responsibility to create this military meteorological service fell to the chief signal officer of the Army, General G. O. Squier, for two reasons. First, Squier had recently formed the Signal Corps Science and Research Division that was headed by physicist Robert Millikan and staffed by many civilian-turned-reservist scientists and engineers. ${ }^{21}$ Second, the Signal Corps controlled the radio and tele-communications of the armed forces and since rapid and reliable communications were vital to an effective meteorological service, efficiency could be improved

\footnotetext{
${ }^{20}$ Annual Report of the Chief Signal Officer to the Secretary of War, 1919 (Washington: Government Printing Office, 1919), 347; Bates and Fuller, Weather Warriors, 18; Raines, Message, 190.

${ }^{21}$ Raines, Message, 170-71; Bates and Fuller, Weather Warriors, 18, Robert Millikan, The Autobiography of Robert A. Millikan (New York: Prentice-Hall, 1950), 156; Bertram Sherry and Alan Waterman, "The Military Meteorological Service in the United States During the War," Monthly Weather Review 47 (1919): 216-17. Millikan retained his position on the National Research Council in conjunction with his new responsibilities as head of the Signal Corps Science and Research Division. Because of his potential work overload, Millikan delegated the task of planning the Meteorological Service to five other Signal Corps officers with considerable experience in meteorology. Millikan spent the majority of the war involved in various research endeavors that included improving sound ranging, gas warfare, and, most prominently, (at least in Millikan's autobiography) developing a submarine detection device to protect international shipping.
} 
if these two operations functioned in the same department. One of the first assignments of the Science and Research Division was to form a task force that could develop a plan to create, train, and deploy an Army meteorological service. ${ }^{22}$ By August, the task force submitted a proposal that called for 475 enlisted men and 27 officers to staff meteorological observation stations at home and abroad. ${ }^{23} 125$ of these personnel were drawn from Weather Bureau staff while the remaining 375 recruits were qualified draftees that were trained in meteorological matters at Weather Bureau facilities and later at the Signal Corps School of Meteorology at Texas A\&M. ${ }^{24}$ Originally called the "Army Meteorological and Aerological Service," the Signal Corps Meteorological Service was created with a three-fold purpose, according to the 1919 report of the chief signal officer:

(a) To provide the American Expeditionary Forces with all the meteorological information needed.

(b) To supply the aviation fields, the coast artillery stations, the ordnance proving grounds, and the gas warfare service within the United States with such meteorological and aerological data as might be useful to them.

(c) To undertake special investigations in military meteorology and related problems. ${ }^{25}$

Parts "a" and "b" delegated the responsibility to provide meteorological support where it was needed both in France and in the United States to the Meteorological Service. Part "c" is notable because it suggests a combination of applied (military) meteorology and academic meteorological research. Investigations included the refinement of the one-theodolite method of

${ }^{22}$ Bates and Fuller, Weather Warriors, 18-19; Raines, Message, 190.

${ }^{23}$ Annual Report, 347. Each of the following sources reports a different total number of officers and observers that were trained and mobilized by the end of the war. Roughly that number stands around 500 to 550, Fuller, Thor's Legions, 10; Robert Millikan, "Some Scientific Aspects of the Meteorological Work of the United States Army," Monthly Weather Review 47 (1919): 210; George Squier, "Meteorological Service of the Army," Monthly Weather Review 47 (1919): 84.

${ }^{24}$ Bates and Fuller, Weather Warriors, 20. Qualifications included graduate level experience in physics, mathematics, electrical, mechanical, or civil engineering, or past work with the Weather Bureau, see Annual Report, 347.

${ }^{25}$ Annual Report, 347. 
observing a pilot balloon ascent in the field, the invention of an altitude regulation apparatus to facilitate the automated dispersal of propaganda leaflets via balloon, and the gathering of meteorological data to create new statistical ballistic wind tables for the artillery. ${ }^{26}$ These meteorological investigations show that meteorological practice in the United States continued to grow as a result of the demands for applied meteorology during the First World War.

Until the Meteorological Service could be formed, trained, and deployed, the A.E.F. was forced to rely on the cooperation of the British and French meteorological services and the forecasts issued by the two American meteorological officers present in France. Majors William Blair and E. H. Bowie had arrived in September 1917 to provide stop-gap meteorological support to the A.E.F. and to prepare for the arrival of the Service by arranging for the extra telegraphic equipment necessary for the Service to function efficiently. ${ }^{27}$ The Meteorological Service began establishing observation stations in the Moselle-Argonne sector and the forecasting center at Colombey-les-Belles issued its first forecasts under the direction of Major Blair in May 1918. ${ }^{28}$

\section{Organization of the Meteorological Service}

The Meteorological Service established a network of weather observation stations throughout France. This network was connected by telegraph to a central meteorological headquarters and to any local military operation that might require emergency warning of changing weather conditions. Each station (at least in theory) was outfitted with a host of

\footnotetext{
${ }^{26}$ Sherry and Waterman, "Meteorological Service," 217-222; Millikan, "Scientific Aspects," 211-14. These investigations will be studied in greater detail below.

${ }^{27}$ Annual Report, 349, 352; Sherry and Waterman, "Meteorology Service," 216; Bates and Fuller, Weather Warriors, 19-20, 22; Flammer, "Meteorology," 17; Fuller, Thor's Legions, 11. Blair and Bowie were two of the five officers who were originally brought to the Meteorological Service by Millikan in the summer of 1917, see above.

${ }^{28}$ Flammer, "Meteorology," 30.
} 


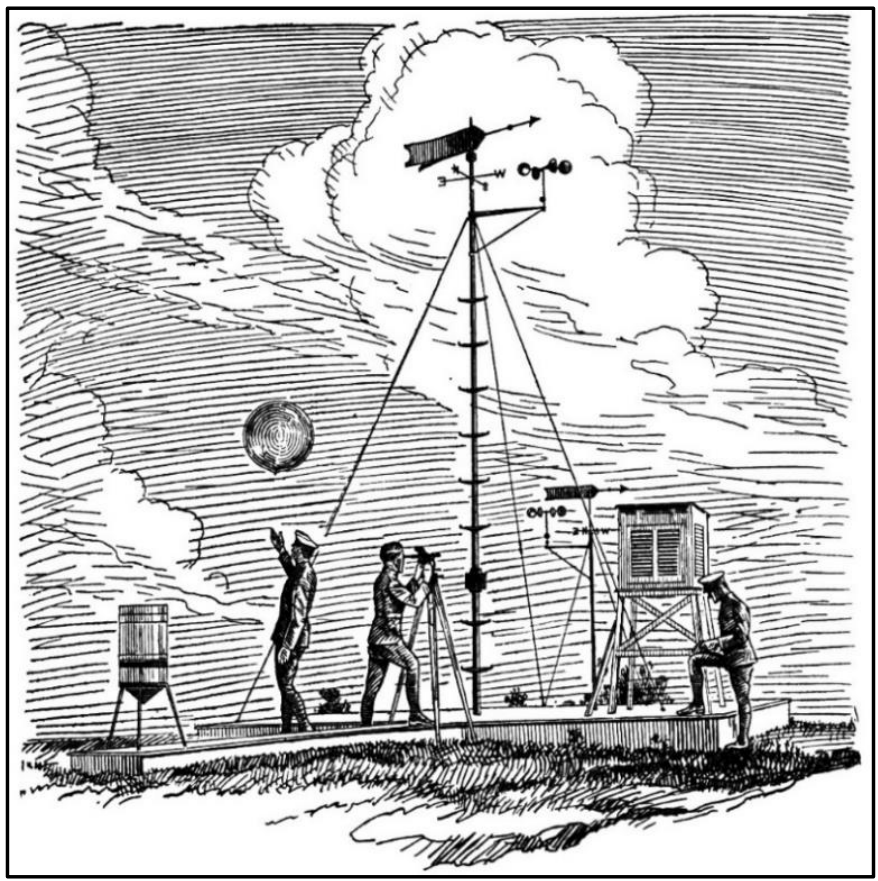

\section{Figure 1}

An illustration taken from the cover pages of the Meteorological Observer training manual showing the beginning of a pilot balloon sounding. Source: Meteorological Observer.

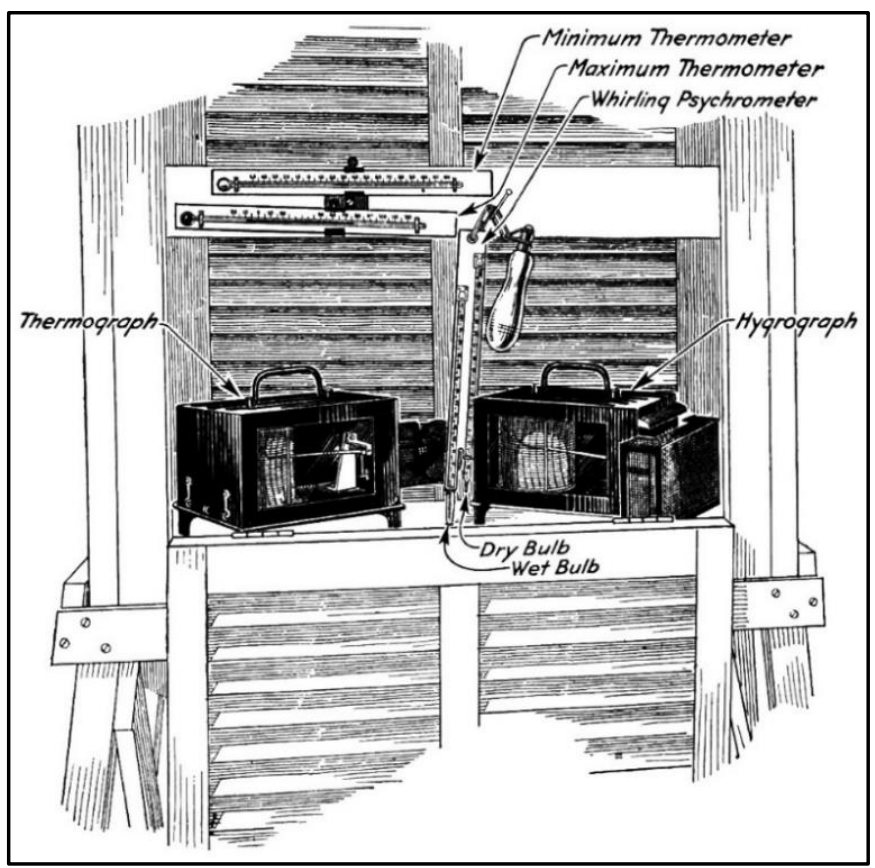

\section{Figure 2}

This instrument shelter contains heat sensitive instruments that need exposure to the free air and shelter from the sun's rays. Source: Meteorological Observer, 5. 
complicated instruments and tools to gather surface and upper air data. Printed in 1925 for use in training Signal Corps cadets, Meteorological Observer: Instructors' Guide for All Arms contains many details about the duties of an observer in the Meteorological Service and what instruments they were expected to operate at their station. ${ }^{29}$ Instruments for measuring surface atmospheric conditions included: thermometers (dry bulb, registering maximum and/or minimum, thermograph), barometers (mercury, aneroid, barograph), hygrometers (whirling psychrometer, hair hygrograph), anemometers (cup, pressure-tube, hand), anemoscopes (wind vanes), a rain gauge, a sunshine recorder, and an electric quadruple register. Instruments for measuring upper air conditions were rubber pilot balloons and theodolites. All of these instruments had to be carefully housed, maintained, and operated in order to guarantee accurate readings over time.

Figure 1 depicts part of a typical observation station and can be used as a simple reference to describe the more notable instruments just listed above. The slotted box on stilts next to the person on the right contains heat sensitive equipment that must be exposed to the free air while remaining shaded from the sun's rays. An interior view is shown in Figure 2 where the maximum and minimum thermometers, a thermograph, a hair hygrograph, and whirling psychrometer are neatly arranged. These instruments facilitated the measurement of atmospheric temperature and humidity at the surface. This information was largely relevant to forecasters because surface visibility and fog conditions could be predicted in advance by regular measurements of humidity and temperature. Forecasts of these conditions were distributed to

\footnotetext{
${ }^{29}$ Meteorological Observer: Instructors' Guide for All Arms (Washington: Government Printing House, 1925). Although this source that I draw most of the following details from describes the ideal operations, training, and equipment of the Meteorological Service circa 1925, I think these ideals remained effectively the same since the founding of the service in 1917. Naturally, it should be kept in mind that wartime stations surely experienced various difficulties and deficiencies with equipment and training that limited each station's effectiveness in one way or another, and that the overall mission of the Meteorological Service may have been more obscure due to its rapid formation.
} 
multiple branches of the armed forces in order to prevent incidents ranging from aircraft accidents to surprise attacks at the front. ${ }^{30}$

At the center of Figure 1 there are two poles mounted with wind vanes and Robinson cup anemometers. The wind vanes are designed with flared tails to be especially sensitive to light winds. The guide also alludes to how the wind vane may betray the location and purpose of an observation station to the enemy. A list of alternate and more inconspicuous tools for measuring wind direction is provided, including flags, smoke, and the proverbial wetted finger. ${ }^{31}$ Robinson cup anemometers record the amount of wind that has passed in a given interval of time. This required the observer to compute the value for wind speed - a process that necessitated careful training - as opposed to simply reading the value from a gauge.

Another notable feature is the arrangement of the two poles; one is about eight feet high while the other is about twenty. This arrangement accounts for the fact that wind conditions can drastically differ between elevations at the near surface level (see Figure 3). Since cloud gas attacks occurred at these low elevations and were reliant on favorable winds, the extremely variable wind conditions of these elevations had to be measured as accurately as possible in order to facilitate better localized forecasts. Thus, the flared tail design of the wind vanes used by the Meteorological Service allowed these sensitive instruments to respond to minute changes in wind direction, and the accurate and constant register of wind speed given by the anemometers alerted observers to rapid changes in wind speed. Effective use of - and defense againstpoisonous gas depended on this meteorological support and necessitated the original expansion of meteorological units in 1915 (see section: Chemical Warfare).

\footnotetext{
${ }^{30}$ Signal Corps Field Manual, Vol. II (Washington: US Government Printing Office, 1931): 167-68.

${ }^{31}$ Meteorological Observer, 57-58.
} 


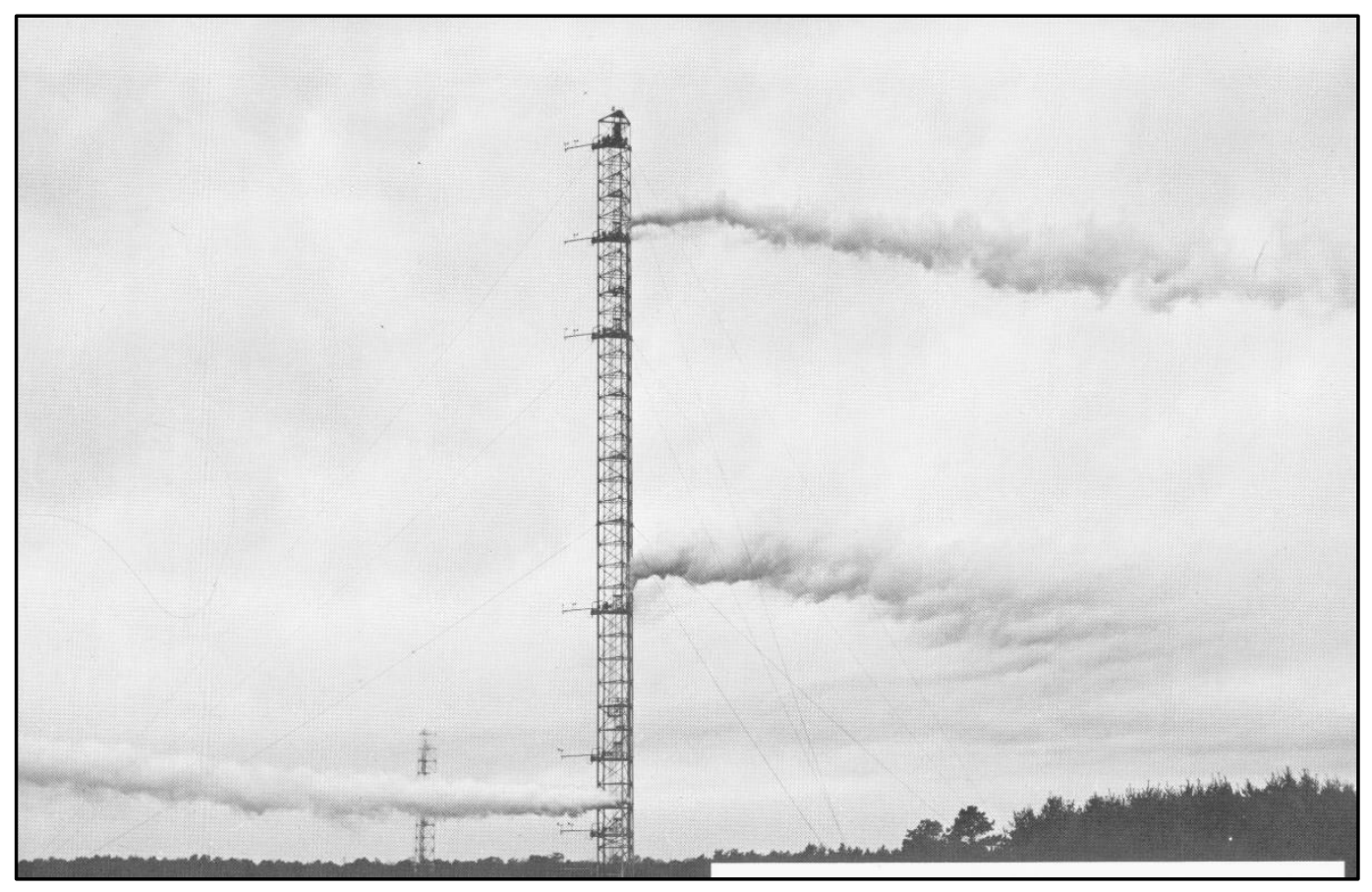

\section{Figure 3}

This image shows how even a gentle difference in wind direction between altitudes can completely alter the wind conditions over a small difference of altitude. Source: Hughes, Weather Service, 136.

The other two people in Figure 1 are in the process of performing a pilot balloon sounding from which they will deduce the wind conditions of the upper air to altitudes approaching 12 miles. Pilot balloon sounding is often the focus of many sources that provide details about the Meteorological Service and its activities during the First World War. ${ }^{32}$ Indeed, Sherry and Waterman claimed that obtaining upper air data was the main outstanding problem of the Meteorological Service to which there were eight possible solutions (see Table 1). ${ }^{33}$

${ }^{32}$ Annual Report, 350-52; Millikan, "Scientific Aspects," 210-11; Sherry and Waterman, "Meteorological Service," 216-21; C. J. P. Cave, "Some Notes on Meteorology in War Time," Quarterly Journal of the Meteorological Society 47 (1921): 9.

${ }^{33}$ Sherry and Waterman, "Meteorological Service," 216-17. 


\begin{tabular}{|l|l|}
\hline \multicolumn{2}{|c|}{ Methods of Gathering Upper Air Data } \\
\hline $\begin{array}{l}\text { Methods that can facilitate the } \\
\text { measurement of temperature, } \\
\text { barometric pressure, humidity, and } \\
\text { wind speed. }\end{array}$ & $\begin{array}{l}\text { Methods that can facilitate only the } \\
\text { measurement of wind speed and } \\
\text { direction. }\end{array}$ \\
\hline $\begin{array}{l}\text { 1. Sounding-balloons } \\
\text { 2. Manned (free) balloons }\end{array}$ & $\begin{array}{l}\text { 1. Pilot balloons } \\
\text { 3. Observation (kite) balloons }\end{array}$ \\
$\begin{array}{l}\text { 4. Kites } \\
\text { 5. Airplanes }\end{array}$ & $\begin{array}{l}\text { 3. Sound-ranging a pilot } \\
\text { balloon which carries a } \\
\text { train of explosives. }\end{array}$ \\
\hline
\end{tabular}

\section{Table 1}

Compiled from information in Sherry and Waterman, "Meteorological Service," 216-217.

Despite the wider range of data gathered by the first column, these five methods were disqualified for one reason or another. Sounding-balloons were slow to deliver the data gathered by its instrument package because the observer had to recover it after it parachuted back to the ground (assuming that it had settled in friendly territory). Manned (free) balloons suffer from this same uncertainty of landing and were also limited in observation ceiling. Kite balloons required expensive reels and motors to operate, were limited in maximum altitude, and were dangerous to operate in high winds. Although proven effective by use in domestic research settings before the war, kites were poor candidates for military use because a kite's steel wires required large open spaces were a local electrical infrastructure would not expose meteorological personnel to the danger of electrocution. Airplanes at this time could not obtain accurate measurements of wind velocity, were vulnerable to enemy interception, and required too much supplemental equipment for consistent operation.

The methods of the second column were limited in the measurements that could be obtained by their use. Since wind direction and speed were the most consequential 
meteorological factors that affected artillery, gas warfare, and the balloon and aviation services, any method that could best gather this data would be highly valued. Observations of anti-aircraft shell bursts and sound-ranging a series of explosions emanating from a pilot balloon were disqualified because their reliance on other branches of the Army would necessitate a complicated divergence of material and servicemen. ${ }^{34}$ This left the pilot balloon as the most reliable, cost-effective, and replicable method to regularly gather and distribute upper air data despite its main limitation of poor visibility in overcast skies.

Pilot balloon sounding necessitated the use of one or more theodolites to track the upward progress of the spherical rubber balloon that was about 80 to 120 centimeters in diameter and sometimes colored red to improve visibility in cloudy conditions. ${ }^{35}$ Originally, two theodolites were stationed at opposite ends of a fixed base line and their simultaneous readings of angle of elevation and azimuth were plotted to show the ascent of the balloon. Upon adoption by the Meteorological Service, the two-theodolite method was immediately improved by using only one theodolite, thus eliminating the need for a measured base line and cutting down on equipment. ${ }^{36}$ Observers could substitute the rate of ascent of a pilot balloon with a pre-calculated value since it was found that pilot balloons ascend at a uniform rate (assuming identical dimensions and inflation pressure), effectively removing the variable that required the other theodolite. Because uniformity in balloon weight was difficult to achieve, a formula for calculating an adjusted rate of ascent for each balloon was developed by Lieutenants W. S. Bowen and H. Anderson at the Signal Corps School of Meteorology. They conducted experiments to generate enough data to

\footnotetext{
${ }^{34}$ Sherry and Waterman, "Military Meteorology Service," 216-17.

35 Sherry and Waterman, "Military Meteorology Service," 217.

${ }^{36}$ Annual Report, 850-51; Millikan, "Scientific Aspects," 210-11; Sherry and Waterman, "Military Meteorology," 221-22. For a detailed, step-by-step description of the sounding process see: Field Manual, $182-86$.
} 
find a statistical average rate of ascent by measuring the descent of various balloons dropped in the interior of a high building. ${ }^{37}$ Despite these improvements the substitution of the ascent variable remained imperfect and one theodolite observations were always less accurate than two theodolite observations. According to Major W. Reed, an officer of the Meteorological Service during the war, observers preferred to have data from one theodolite observations spread over a wide area as opposed to more accurate two theodolite observations from only a few locations. ${ }^{38}$

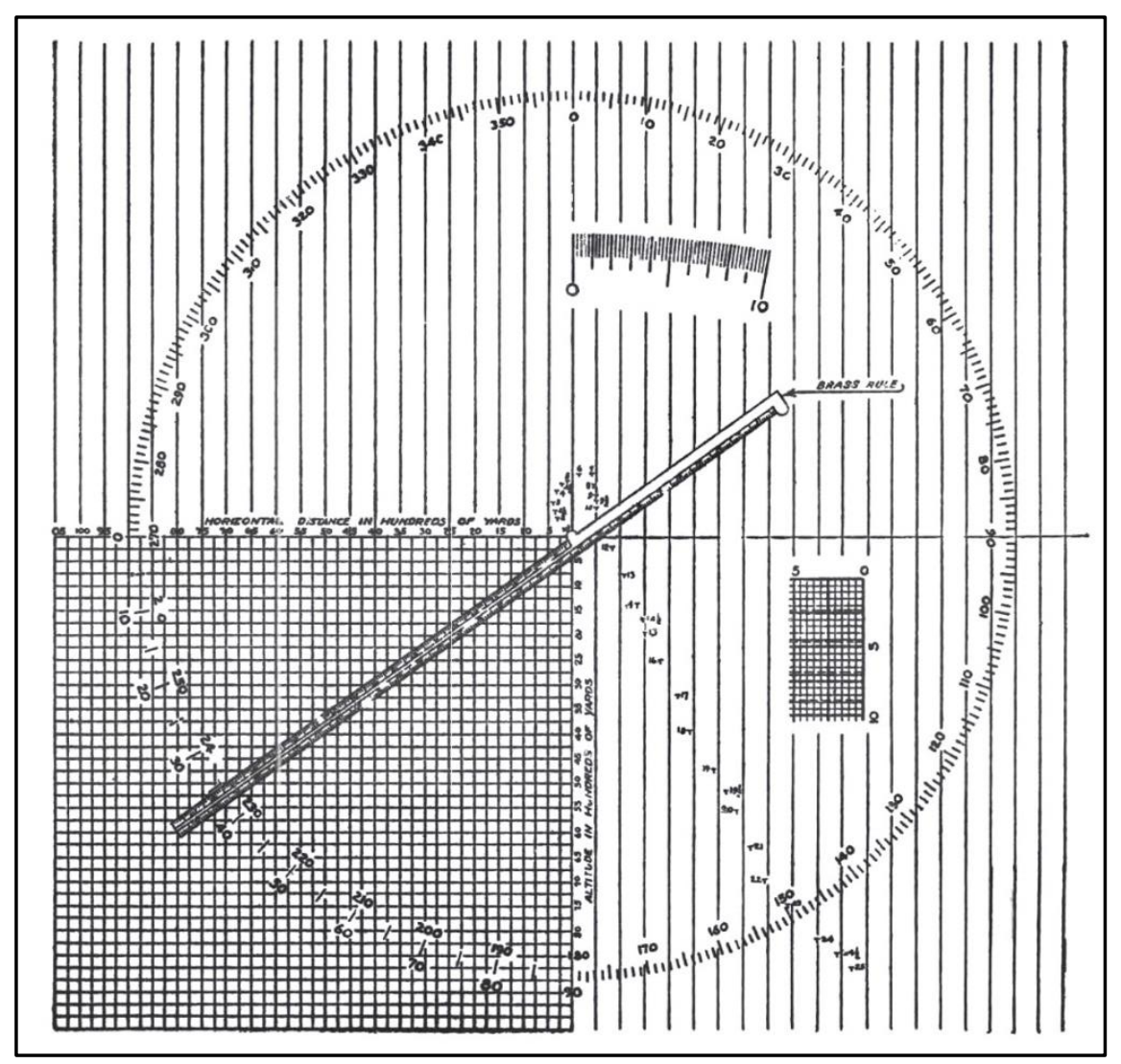

\section{Figure 4}

This ML-55 plotting board was used to track the relative position and altitude of an ascending pilot balloon in order to show wind speed and direction. This figure shows a plotted balloon ascent beginning in the center and turning to the bottom right. Source: Meteorological Observer, 239.

\footnotetext{
${ }^{37}$ Annual Report, 850-51.

${ }^{38}$ William Reed, "Military Meteorology," Geographical Review 12 (1922): 408-9.
} 
Most meteorological observation stations supporting the A.E.F. in France and the armed forces in the United States were equipped to regularly sound the upper air with a single theodolite. Soundings were routinely carried out at least three times a day—more if local combat operations required more frequent updates. ${ }^{39}$ A typical sounding consisted of a 21 step process where one observer (after the balloon was properly inflated with hydrogen from a cylinder) released the balloon while another observer tracked its upward progress with a theodolite. Following a stopwatch or automatic buzzer, the angles of elevation and azimuth were recorded at regular intervals on "Form 201-Met'l" until sight of the balloon had been lost. ${ }^{40}$ The recorded data was then transferred to a number of plotting boards and charts (see Figure 4) to quickly deduce wind data for use by gas warfare officers, aviators, and the artillery.

Figure 4 contains the results of a pilot balloon sounding and graphically represents multiple registers of wind data. The center of the chart is the launch point of the balloon and each tick-mark is the position of the pilot balloon after one fixed interval of time. By comparing the line of these tick-marks to the epicenter of the chart the observer could determine the direction of the wind at known altitudes (given that pilot balloons ascend at a regular rate). This chart shows that the winds near the surface were blowing the pilot balloon toward the north-northwest and shifted to the south-southeast as the balloon reached higher altitudes. By comparing the distance between each tick-mark the observer could also determine wind velocity between points. The greater the distance between tick-marks, the greater distance the balloon traveled from the

\footnotetext{
${ }^{39}$ For instance, areas under threat of gas attack required multiple soundings per hour in order to monitor wind conditions, Meteorological Observer, 361 . This topic will be covered in more detail in coming sections.

${ }^{40}$ Meteorological Observer, 221-25, 231-32.
} 
epicenter in the fixed interval of time and therefore, the higher the wind speed. In one chart, relevant wind condition data at a range of altitudes could be quickly and efficiently communicated to artillery, aviation, and gas warfare officers.

Finally, the last important instrument of a typical station was a triad of barometers that facilitated the measurement of atmospheric pressure at surface level. Barometers are not included in Figure 1 because a mercury barometer cannot be exposed to wind or direct sunlight, and aneroid barometers and barographs are susceptible to damage from sudden pressure changes (such as the firing of a nearby artillery piece). ${ }^{41}$ Barometric readings required the observer to calculate a correction for the elevation and temperature of the instrument in order to arrive at a standardized result. Tracking the parabolic trend of barometric pressure (easily facilitated by following the line of the barograph) was important because a sudden drop in barometric pressure could indicate the approach of a storm. ${ }^{42}$ Sudden storms were especially dangerous at a time when a whole squadron of aircraft could be blown away and wrecked if caught out on an airfield during a storm or passing squall line. The Meteorological Service was expected to watch for these drops in pressure and issue storm warnings to nearby aerodromes. ${ }^{43}$

Clearly these meteorological observation stations were well equipped to gather a wide range of data and could be expected to guarantee a high level of accuracy. The key structure that facilitated the fully effective operation of these stations was the sophisticated and efficient communications system that linked these stations to the central Meteorological Service

${ }^{41}$ Meteorological Observer, 27-29.

${ }^{42}$ Meteorological Observer, 25.

43 Annual Report, 356; William Blair, "Meteorology for Aviation," Proceedings of the American Philosophical Society 67 (1928): 291-92: "no squall or local storm arrived at that part of the front occupied by the American Forces, the arrival of which had not been individually announced to all units affected." 


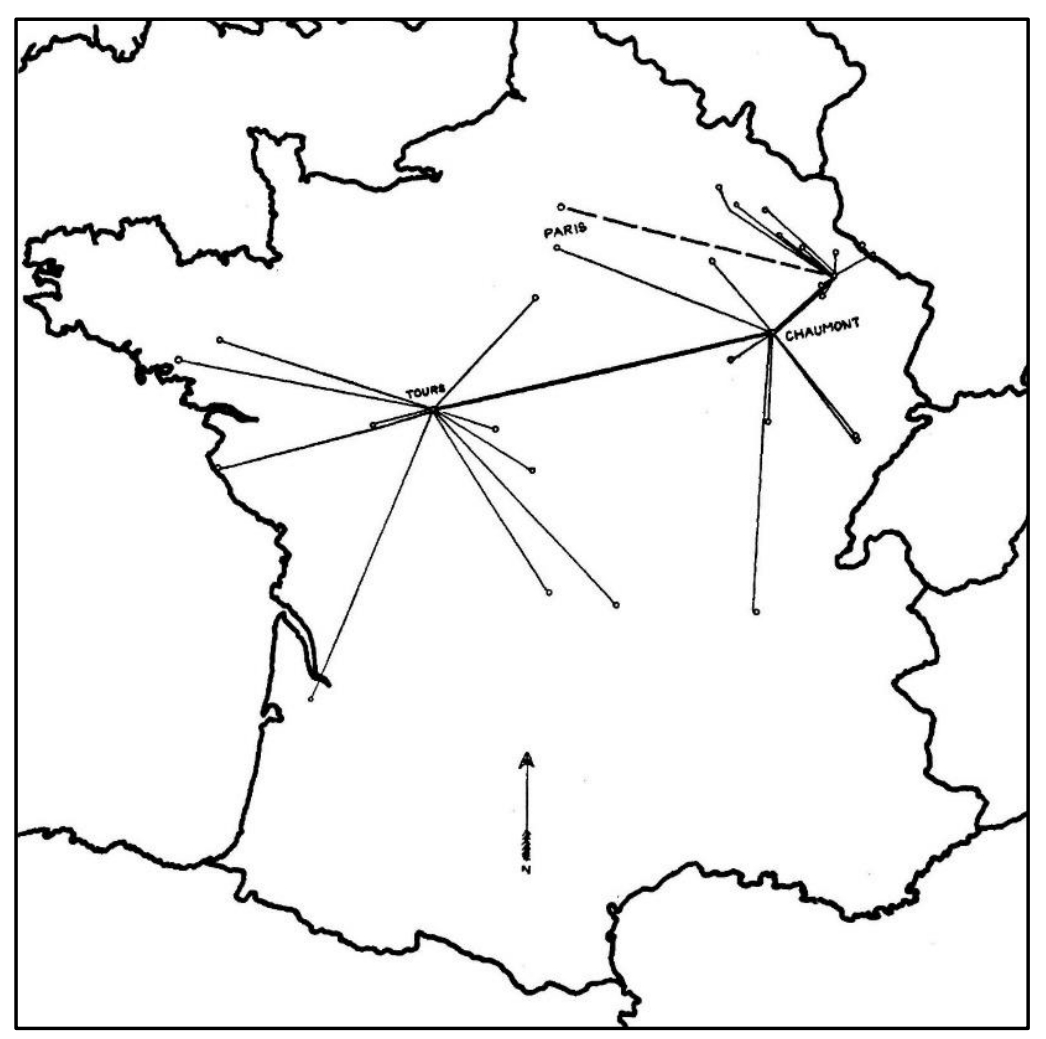

\section{Figure 5}

Each dot represents a meteorological observation station connected by (telegraph) lines to the forecasting headquarters at Colomby-les-belles, near Chaumont. Source: Blair, “Aviation,” 289-290.

headquarters. ${ }^{44}$ Figure 5 shows the approximate location of each important observation station and its connection to the communications network that brought all data to the weather forecasting headquarters at Colombey les Belles. ${ }^{45}$ This network was trafficked four times a day by meteorological messages that carried data for two forecasts, issued at $6 \mathrm{pm}$ and $8 \mathrm{am} .{ }^{46}$

Observation stations at the front were established in pairs to stagger the observation duties by the hour in order to lower radio traffic. These stations were also prepared to provide meteorological

${ }^{44}$ Annual Report, 356; According to the chief signal officer's annual report, thoroughly reliable day-and-night transmissions of meteorological messages was one of the two most essential factors that contributed to the success of the Meteorological Service. The other essential factor was the recruitment support provided by the Signal Corps Science and Research Division.

45 Blair, "Aviation," 289-90.

${ }^{46}$ Annual Report, 355, Meteorological Observer, 355. 
data and storm warnings directly to relevant units via telephone or wireless. ${ }^{47}$ The work of this expansive network of observation stations was facilitated by the communications technology that enabled the rapid transmission of weather data across France. Control of this communications network was one of the main reasons for why the Signal Corps was given the responsibility of administering military meteorology in 1917.

\section{Military Applications of Meteorological Support}

The Signal Corps Meteorological Service was designed to facilitate meteorological observation and forecasting for the A.E.F. as well as the rest of the incoming American armed forces. Many branches of the armed forces could utilize some form of meteorological support, including: the artillery, counter-battery sound-ranging units, offensive and defensive gas warfare companies, powered flight and balloon aviators, high command, and the Army Corps of Engineers. Most scholarship on the history of meteorology simply provides a short summary of these needs. ${ }^{48}$ What follows is a more detailed description of these meteorological needs beginning with the foremost user of meteorological data before the expansion of gas and aerial warfare, the field artillery.

\footnotetext{
${ }^{47}$ Annual Report, 353. For instance, a gas unit trying to make an attack may require up to four wind condition reports every hour in order to surprise the enemy the moment the wind become favorable, see Meteorological Observer, 355.

${ }^{48}$ Bates and Fuller, Weather Warriors, 17; Harper, Numbers, 43-44; Flammer, "Meteorology," 11-16; Fuller, Thor's Legions, 9; Harper, "Boundaries of Research,” 85-88; Harper, “Meteorology’s Struggle,” 192-93; Raines, Message, 190.
} 


\section{Field Artillery}

As the militaries of Europe clashed in the Balkans, France, and Poland during the opening months of the First World War, the lack of meteorological data available for military use was primarily felt by the artillery. Traditionally, artillerymen ensured accurate fire by "zeroing in" their guns. This process entailed firing rounds at a fixed target and, after observing the results of this volley, re-laying the guns with the necessary corrections for the next volley. By 1914, artillery pieces could easily achieve ranges that exceeded the observational limit of the naked eye which made it impossible for an artillery battery to watch the results of their preliminary zeroing shots. Although another observation party could relay the results of the shots back to the battery via radio or written message, “zeroing in" required too much time, wasted shells on preliminary shots, and could not maintain the element of surprise in the case of a shock assault. If an artillery battery was to provide accurate and effective support then it had to account for all the mechanical and meteorological factors that may divert a shell during its trajectory through the atmosphere and apply the necessary corrections for these factors on the first volley.

Mechanical influences included the powder load of a shell, the age of the artillery piece, and the weight of the shell being used. These mechanical influences on the trajectory of a shell were easily determined by an experienced artillery crew already familiar with their practice and equipment. On the other hand, the meteorological factors that affected a shell in flight were elusive and complicated to measure. The meteorological factors were counted as four in number during the war: temperature, atmospheric pressure, hygrometric (humidity) condition, and wind speed and direction. ${ }^{49}$ These five conditions needed to be known at all altitudes beginning at the

\footnotetext{
49 Taken from the Table of Contents of Notes on the Meteorologic Elements Affecting Artillery, translated by the Army War College (Washington: Government Printing Office, 1917). This is another example of a borrowed
} 
muzzle of the gun to the ceiling of the shell's trajectory if fire was going to be accurate. For example, Bertram Sherry and Alan Waterman's article in the Monthly Weather Review included a general example of the effect of an opposing wind on a projectile: "[F]iring the 75-mm gun at a target 7,000 meters away an opposing wind of 10 meters per second will cause the projectile to fall nearly 400 meters (a quarter of a mile) short of the target." ${ }^{" 50}$ Clearly, a modern artillery detachment required accurate and current meteorological data to provide support at long ranges.

Measuring these conditions was an assignment that required specialized training and timeliness in order to be effective. A typical Meteorological Service observation station was well prepared to gather and distribute this weather data. A thermometer, barometer, and psychrometer could provide surface values of temperature, pressure, and humidity, while a pilot balloon sounding could determine the wind conditions of the upper air.

The mathematically distilled average correction for the wind conditions in each layer of atmosphere (about 1,500 feet deep) encountered on a projectile's trajectory was known as a "ballistic wind." 51 Arriving at this figure required both meteorological personnel and artillerymen to utilize numerous tables and charts to graphically compute the raw meteorological data into a simple correction value. Alongside the gathering of this meteorological data, the

document that hints at how rapidly the United States mobilized for war and how haphazardly its military leaders attempted to learn from the mistakes that their allies had made during the previous three years of trench warfare.

${ }^{50}$ Sherry and Waterman, "Meteorological Service," 215; Annual Report, 349-50; Cave, "Notes on Meteorology," 7; H.G. Lyons, "Meteorology During and After the War," Monthly Weather Review 47 (1919): $82-$ 83; Reed, "Military Meteorology," 407-8; George Burgess, "Applications of Science to Warfare in France," The Scientific Monthly 5 (1917): 293-94. 186.

${ }^{51}$ Sherry and Waterman, "Meteorological Service," 219; Reed, "Military Meteorology," 407; Field Manual V.2, 
Meteorological Service's tasks included the development of similar, region and gun specific, charts and calculating aids to be issued to all batteries in the United States and France. ${ }^{52}$

By the end of the war, the Meteorological Service was supplying American artillery detachments with meteorological data and ballistic wind values relevant to their geographic location, enabling a detachment to provide accurate artillery support while minimizing the undue waste of shells. ${ }^{53}$ Robert Millikan (originally tasked with forming the Meteorological Service in 1917) claimed that "[a]t the time of the signing of the armistice on the western front the Air Service and all the artillery were being furnished every two hours with the temperature, density, wind velocity, and direction, taken at the surface and at various altitudes, from 100 to 500 meters apart, up to 5,000 meters." ${ }^{, 54}$ By the end of the First World War, any battery without close meteorological support could not meet the increased level of sophistication and performance that artillery was now expected to achieve.

\section{Sound Ranging}

The Sound Ranging Section, the Gas Regiment, and the Air Service were three new branches of the armed forces that required meteorological support in order to function. Sound ranging was developed during the war and was a highly specialized and sensitive form of counter battery work based on the principles of acoustic physics. Artillery batteries were often highly camouflaged to avoid detection — and subsequent bombardment—by the enemy. Detection could be facilitated by aerial observation (from both planes and tethered balloons), by flash spotting

\footnotetext{
${ }^{52}$ Annual Report, 349-50; Millikan, "Scientific Aspects," 210; Sherry and Waterman, "Military Meteorology," 216.

53 Sherry and Waterman, "Meteorological Service," 216.

${ }^{54}$ Millikan, "Scientific Aspects," 210.
} 
(deducing location by correlating muzzle flashes and artillery reports), and by sound ranging. Although it required specialized listening equipment and complicated mathematical processes to render usable data, sound ranging could be used to determine the location, caliber, and number of shots fired from an enemy battery with exceptional accuracy. ${ }^{55}$

In short, a battery was located by registering the arrival of the sound wave generated by the charge of an artillery piece as it traveled across a measured baseline. When these minor differentiations in the sound wave's time of arrival (measured in hundredths of a second) were triangulated with the readings from multiple locations, the location of the battery could be determined via triangulation (see Figures 6 and 7). ${ }^{56}$ Since the speed of sound waves through
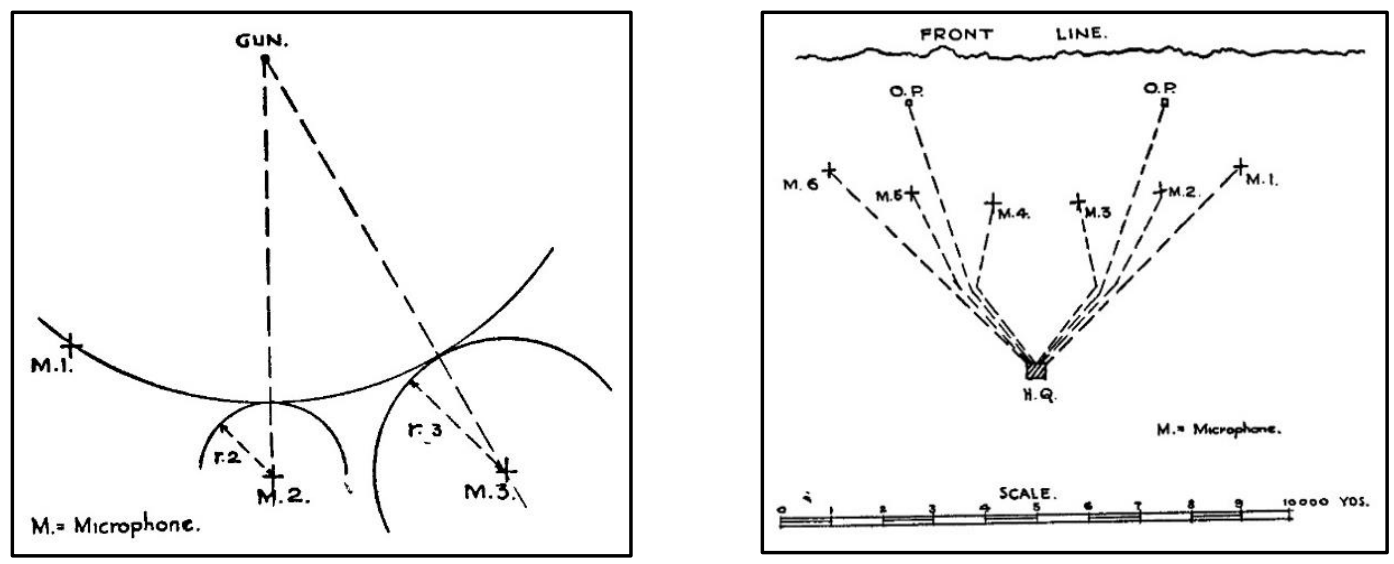

\section{Figure 6 and Figure 7}

Figure 6 (left) illustrates how the position of an enemy gun could be graphically calculated while Figure 7 (right) shows an ideal frontline arrangement of microphone "listening" stations that could record the arrival of a sound wave once switched on by a forward observation post. Source: Innes, Flash Spotters, 130, 132.

\footnotetext{
${ }^{55}$ Burgess, "Applications," 291. There is a discrepancy between sources that attest to the high precision of sound ranging and later scholarship that describes it as "woefully inaccurate." Sources that favorably describe sound ranging: Lyons, "Meteorology," 83; Millikan, "Scientific Aspects," 211-14; Daniel Kevles, The Physicists (New York: Alfred S. Knopf, 1977), 126-31; John Innes, Flash Spotters and Sound Rangers: How They Lived, Worked and Fought in the Great War (London: George Allen \& Unwin, 1935) 127-38; and sources that criticize the effectiveness of sound ranging: Flammer, "Meteorology," 13; Harper, Numbers, 42; Harper, "Meteorology's Struggle," 193.

${ }^{56}$ Harry Bateman, "Mathematical Theory of Sound Ranging," Monthly Weather Review 46 (1918): 4-11. 4, see above.
} 
the atmosphere is relevant to the composition of said atmosphere, sound ranging is affected by temperature, humidity, barometric pressure, and wind conditions. Considering that sound ranging calculations had an extremely narrow margin of error, accurate meteorological data was vital to the effective operation of a sound ranging unit. The Meteorological Service was equipped to regularly gather this data at the surface, and wind conditions at higher elevations if necessary. ${ }^{57}$ Without this meteorological data — especially that of the wind conditions - no correction for its effects on the travel of sound waves could be applied and attempts at sound ranging would have been futile.

\section{Chemical Warfare}

Poison gas, perhaps the most infamous innovation of the First World War, was a novel weapon that was completely dependent on close meteorological support, especially in its early form. Gas was first deployed effectively en masse by Germany on the evening of April 22, 1915 near the small Belgian town of Ypres. After a brief German artillery bombardment, a mysterious haze was spotted to be gathering over the German trenches. Eventually the haze gathered into a greenish cloud that slowly crept along only a few feet from the ground. The light winds carried the gas across no-man's-land and into the Allied trenches, forcing the French colonial troops to either abandon their positions or be asphyxiated. ${ }^{58}$ The first major poison gas attack at Ypres utilized about 6,000 cylinders to release chlorine gas from a $7 \mathrm{~km}$ section of the German front

\footnotetext{
${ }^{57}$ Bateman, "Sound Ranging," 4; Reed, "Military Meteorology," 407-8.

${ }^{58}$ Dietrich Stoltzenberg, Haber: Chemist, Nobel Laureate, German, Jew (Philadelphia: Chemical Heritage Press, 2004), 138; Albert Palazzo, Seeking Victory on the Western Front: The British Army and Chemical Warfare in World War I (Lincoln: University of Nebraska Press, 2000), 41-42; Simon Jones, World War I Gas Warfare Tactics and Equipment (Oxford: Osprey Publishing, 2007), 5; Charles Heller, Chemical Warfare in World War I: The American Experience, 1917-1918 (Fort Leavenworth: Combat Studies Institute, 1984), 7-9.
} 
line trenches. ${ }^{59}$ This early form of delivering poison gas was used during the first years of widespread chemical warfare despite its complete dependence on meteorological conditions, especially the direction and speed of surface winds.

Robert DeCourcy Ward's previously mentioned series of articles include a few considerations of the meteorological aspect of cloud gas warfare. As early as June, 1915, Ward mentioned an event that grimly highlights how both the recipient and the perpetrator of a cylinder gas attack were at the mercy of the winds once the chemical gathers in the atmosphere. "[T]he wind which, on one occasion, had been carrying the deadly asphyxiating gases used by the Germans towards the Allies' trenches, suddenly changed, blowing these same gases back to the German lines, and forcing the men to flee for their lives." ${ }^{\prime 60}$ This report emphasized the importance of predicting the behavior of the wind as accurately as possible leading up to a cloud gas attack. In the next article of his series, Ward surmised that the German meteorological observers must have possessed a system to carefully predict the wind conditions before their gas attacks because of the infrequent occurrence of easterly winds in Western Europe. ${ }^{61}$

By the time the Meteorological Service was fully operational in France, gas warfare had changed. New gases like phosgene and mustard gas were often delivered in artillery shells (as opposed to clouds) and attacks were harder to predict because preparation for an attack was quicker and the cooperation of the wind was no longer absolutely vital. The Meteorological Service continued to support chemical defense measures by issuing warnings to sectors where

\footnotetext{
${ }^{59}$ Ludwig Haber, The Poisonous Cloud: Chemical Warfare in the First World War (Oxford: Clarendon Press, 1986), 34 .

${ }^{60}$ Robert Ward, "The Weather Factor in the Great War: Late Winter and Spring," Journal of Geography 13 (1915): 317.

${ }^{61}$ Ward, "Weather Factor: III," 75.
} 
the weather favored an enemy gas attack. ${ }^{62}$ Like the artillery's need for meteorological support, the offensive use of gas entailed the application of meteorological data to minimize waste and increase the chances of success on the first attack in order to surprise and poison the enemy before they could don their gasmasks. Support would have to be extremely localized to account for an area's topography and observations had to be frequently taken to watch for any unfavorable changes in wind speed or direction. ${ }^{63}$ Tools like the previously mentioned anemometers and wind vanes were used to record current surface conditions at multiple elevations while pilot balloon soundings facilitated the tracking of changes in upper air conditions which could indicate future changes in surface wind behavior. By the end of the war, the deployment of effective gasmasks and the use of more sophisticated gas delivery methods had lessened the effect of meteorological conditions on gas warfare, but efficient and localized meteorological support was still necessary to prevent self-inflicted gassings and surprise gas raids by the enemy.

\section{Aerial Operations}

The most urgent call for meteorological support emanated from the Signal Corps Aviation Section (known as the Army Air Service after 1918). This service required a steady supply of data and condition reports to protect its fragile equipment and the lives of its aviators. Almost every aspect of the Air Service's operations were affected by meteorological conditions,

\footnotetext{
${ }^{62}$ Burgess, "Applications of Science," 293; Reed, "Military Meteorology," 410; Cave, "Notes on Meteorology," 7; Lyons, "Meteorology," 81-82. According to Lyons, the British formed their meteorological section as a branch of the Royal Engineers to support the Special Brigade (responsible for chemical warfare) as well as the Royal Flying Corps.

${ }^{63}$ Reed, "Military Meteorology," 410, Annual Report, 354, 356.
} 
including balloon observations, aircraft flight (especially takeoff and landing), and aerodrome construction and maintenance.

High winds, particularly those associated with a passing squall, threatened tethered observation balloons and the wood and canvas airplanes of the time. Gusts could easily carry away and smash loose aircraft or break the tethers anchoring a balloon to the ground. A strong wind in the wrong direction could also cause a flight of aircraft to drift and miss their intended target or destination, leaving them without a designated (or friendly) airfield to land at. ${ }^{64}$ Cloud and fog conditions could also pose a problem to aviators, for instance, a low blanket of clouds could make an accurate bombing raid futile and - upon returning from this failed night raid — the flight may find that a morning fog has completely obscured their landing strip. ${ }^{65}$

The Meteorological Service was required to determine wind and cloud conditions at necessary flight altitudes as well as issue emergency storm warnings in order to support the Air Service's operations. ${ }^{66}$ Pilot balloon soundings and cloud observations were employed to gather wind and cloud data which was regularly distributed to local aviation and balloon officers. ${ }^{67}$ This data was used by aviators to determine a wind correction value for navigation and bomb dropping while reconnaissance balloon officers used these reports to keep their balloons in the air as long as conditions possibly allowed. Although by the end of the war new techniques and technologies allowed aviators to fly in increasingly hostile conditions (high winds, through

\footnotetext{
${ }^{64}$ Meteorological Observer, 353.

${ }^{65}$ Reed, "Military Meteorology," 405-6.

${ }^{66}$ Annual Report, 352; Blair, "Meteorology for Aviation," 291.

${ }^{67}$ Reed, "Military Meteorology," 407. The usefulness of this data was greatly appreciated after an episode in which a balloon officer disregarded the Meteorological Service's weather report and had to pull his balloon back down after his winch began to rise from the ground; see Annual Report, 353.
} 
clouds, in heavy rain, etc.), the need for meteorological support was not lessened. ${ }^{6}$ Indeed, after the armistice the Meteorological Service's largest request for support was consistently from the Army Air Service which eventually came to absorb the meteorological duties of the Signal Corps in 1937.

\section{Army Corps of Engineers}

The Meteorological Service also used statistical meteorology to support the construction of more-or-less permanent military facilities. Statistical meteorology refers to using the vast record of past meteorological reports for a specific region to determine estimates of future conditions like the average intensity and direction of winds, average number of days with good visibility, or the average number of foggy mornings at a particular location. Determining the location of a new airdromes required the most consideration of statistical meteorology prior to its construction. ${ }^{69}$ Locations had to be found with the lowest average number of foggy days and a regular wind direction in order to orient the hangar and landing strip accordingly and to help ensure that the airdrome did not close due to unsafe weather conditions. Other facilities, like artillery and chemical warfare training sites, needed to take average visibility and wind conditions into account in order to operate effectively and with as little interference from the weather as possible.

\footnotetext{
${ }^{68}$ Robert Ward, "The Weather Controls Over the Fighting During the Summer of 1918," The Scientific Monthly 7 (1918): 296; Robert Ward, "Weather Controls Over the Fighting During the Spring of 1918," The Scientific Monthly 7 (1918): 24-33.

69 Reed, "Military Meteorology," 405; Meteorological Observer, 348.
} 


\section{Forecasting}

Probably the most common form of support rendered by the Meteorological Service, forecasting was a highly technical and sophisticated data gathering and synthesizing process by which nearly every branch of the A.E.F. was regularly updated on their local weather conditions. What follows is an example forecast report issued to American forces stationed in the Argonne sector in November.

Forecast A1. Argonne until 6p.m. 1 Nov.

A. Weather fair for all arms except for aviation and observation in the forenoon.

B. Surface winds, $1-5 \mathrm{~m} / \mathrm{s}$ East.

At 2,000 meters, $3-8 \mathrm{~m} / \mathrm{s}$ East to Southeast.

At 5,000 meters, $4-8 \mathrm{~m} / \mathrm{s}$ Southwest to West.

C. Overcast, with occasional large clear spaces in forenoon.

Clear to one-half cloudy in afternoon.

Fog until afternoon, Haze all day.

D. Cloud height, 3,000 m. with occasional lower masses 1,200 m.

E. Visibility, very poor, $1-2 \mathrm{~km}$. until noon, improving to 3 to $5 \mathrm{~km}$. in afternoon.

F. No rain.

G. Maximum temperature, $10^{\circ} \mathrm{C}$.

$\mathrm{K}$. Odds in favor of forecast, $6-1$.

Issued at 6:10 a.m. ${ }^{70}$

A forecast like this was tailored to meet the basic meteorological needs of all the

branches of the A.E.F. as outlined above. For instance, section B lists wind conditions at multiple elevations which are readily usable by the artillery for rudimentary wind corrections and for gas offense and defense at the front line. If surface winds were forecasted to be blowing north or west, then the whole sector would most likely remain on gas alert until the next forecast indicated more favorable conditions. This forecast was one of two for the next 24-hour period, the other being issued around 8 a.m. ${ }^{71}$ Forecasts for conditions up to a week in advance could also be issued on request in order to help facilitate planning of an offensive or the spoiling of an

\footnotetext{
${ }^{70}$ Blair, "Meteorology for Aviation," 293.

${ }^{71}$ Annual Report, 355.
} 
enemy's preparations to take advantage of a favorable spell of good weather. ${ }^{72}$ The military application of this forecast is also encapsulated by its direct language and the included estimation of the strength of the prediction (section $\mathrm{K}$ ). The elimination of qualifying terms such as "probable" and "possibly" helped these forecasts appear clearer and more reliable to the officers in the field. ${ }^{73}$ This more confident language implied that the forecasts issued by the Meteorological Service had achieved a greater level of accuracy compared to the pre-war domestic forecasts of the Weather Bureau.

Although this belief helped facilitate confident decision-making at the front, the empirical forecasting methods of the Meteorological Service during the First World War were effectively the same as those provided by the Signal Corps fifty years ago during the Civil War. Forecasts were built by constructing a series of synoptic weather maps that charted various meteorological data (isobaric pressure, temperature, wind conditions, etc.), then consulting the best available archive of past meteorological data for the concerned region and time, and finally applying a wealth of personal experience in meteorological work to make an educated prediction of future weather conditions. ${ }^{74}$ Essentially, this process was effective enough to meet the needs of the A.E.F. during the war, but many meteorologists were continually frustrated with its limitations,

\footnotetext{
${ }^{72}$ Meteorological Observer, 351.

73 Blair, "Meteorology for Aviation,” 294-95; Annual Report, 355; Reed, “Military Meteorology," 409. According to Blair, a forecast with a confidence ratio less than 3 to 1 would be replaced by a better forecast as soon as possible.

${ }^{74}$ Alexander McAdie, "Meteorology and the National Welfare," The Scientific Monthly 6 (1918): 186; C. K. M. Douglas, "The Evolution of $20^{\text {th }}$-Century Forecasting in the British Isles," Quarterly Journal of the Royal Meteorological Society 78 (1952): 2; Richard Reed, "The Development and Status of Modern Weather Prediction," Bulletin of the American Meteorological Society 58 (1977): 390-91.
} 
namely, its lack of formulaic rigor and its reliance on the "untrainable" experience of a seasoned forecaster. $^{75}$

By the end of the war, changes in the scope and procedure of empirical forecasting were beginning to become formalized into general practice. For instance, the requirement of a background in physics or mathematics in order to be accepted into the Signal Corps School of Meteorology reflected the increasing tendency to relate the physics of the air to forecasting and the study of meteorology in general. ${ }^{76}$ Another change in scope was the conception of the atmosphere as a layered, interactive, three-dimensional body which had to be regularly sounded and included as a piece in the synoptic charting series. ${ }^{77}$ In decades preceding the First World War, the value of upper-air data to forecasting was advertised by aerologists - those concerned specifically with studying the upper-air. By 1918, military technologies like aircraft and artillery brought the regular study of these higher layers of the atmosphere into the scope of meteorology. These changes in scope and procedure show that, as a result of its military application, meteorological practice had been driven to a higher level of complex procedure that required at least advanced training to carry out. Although these trends support the conclusion of a general shift from empiricism to a dynamic science of meteorology, this shift was slow, especially in the

\footnotetext{
${ }^{75}$ Napier Shaw, "Meteorology: The Society and its Fellows," Quarterly Journal of the Royal Meteorological Society 45 (1919): 101-2, 106. Interestingly and somewhat contradictorily, Shaw criticizes the limited capacity of the current forecasting system and its reliance on time-earned experience in place of physical laws and processes while later espousing the usefulness of the untrained volunteer amateur weather observer. I think his defense of the so-called "weather diarist" is a reflection of the common disparity between available funds and the need for an increasingly larger observation net. These amateur observers could only collect a relatively narrow range of data considering the upper-air soundings required for current meteorological work.

${ }^{76}$ Homer Ball, "Meteorological Course Given in the Signal Corps School at Camp Vail, N.J., During 1920," Monthly Weather Review 49 (1921): 86; Blair, "Meteorology for Aviation," 294-95; Reed, "Military Meteorology," 410.

${ }^{77}$ William Blair, "Exploration of the Upper Air by Means of Kites and Balloons," Proceedings of the American Philosophical Society 48 (1909): 33; Mark Harrington, "Systematic Exploration of the Upper Air with Estimates of Cost," Monthly Weather Review 42 (1914): 619-21.
} 
United States where meteorology continued to have a minimal academic and research presence after the war. $^{78}$

\section{Armistice and Demobilization}

At the conclusion of hostilities on the Western Front in 1918, the Meteorological Service was a fully-functioning organization that provided first-rate meteorological support for a diverse range of military applications. The end of the war also meant that the Meteorological Service would have to transition into a peacetime service. Regardless of the relatively sudden integration of meteorology into military practice during the war, the Meteorological Service remained an essential department of the U.S. Army that would not be disbanded or merged with the Weather Bureau simply because the "emergency" was over. In fact, at least fifty-one meteorological stations were estimated to be necessary to provide adequate support during peacetime. ${ }^{79}$ This demand for peacetime meteorological support shows that military meteorology had become an integrated and indispensable facet of a modern armed force over the course of a single conflict.

Unfortunately, the rapid demobilization of the A.E.F. after the armistice greatly contributed to the Meteorological Section's struggle to make this transition and to continue providing meteorological support to military and civilian organizations. Scholars tend to characterize this demobilization period as a "race for home." ${ }^{80}$ At the head of this race were

\footnotetext{
${ }^{78}$ For example, one of the few options for higher level study of meteorology during the war was a series of ten lectures given by Robert DeCourcy Ward through MIT that included instruction on the relation of the physics of the air to forecasting or understanding meteorological behavior, see "Syllabus of Lectures on Meteorology," Monthly Weather Review (1917): 298.

${ }^{79}$ Flammer, "Meteorology," 33-34, these fifty-one stations were a combination of the various requests for meteorological support stations from the Coast Artillery (thirty-five), the artillery (four), the Ordinance Corps (two), and the Air Service (ten).

${ }^{80}$ Bates and Fuller, Weather Warriors, 23; Harper, Numbers, 43.
} 
Meteorological Service personnel both in France and the United States (including Lt. Col. Robert Millikan) who wished to return to civilian occupations and to avoid the "absurdly low salaries"

they expected to earn in a peacetime army. ${ }^{81}$ Despite training over 500 meteorological personnel for wartime work, by April 1919 the Meteorological Service failed to retain more than eleven officers and forty-nine enlisted men to staff only eleven stateside stations out of the fifty-one estimated to be necessary for peacetime operations. ${ }^{82}$ This severe shortage of trained personnel was combined with a deficient budget and a steady increase in responsibility which led the Meteorological Service to perform at a level consistently below its standard set during the First World War.

\section{The Signal Corps Meteorological Service: Interwar Conflicts and Dissolution}

\section{New Directions and Developments}

Understaffed and underfunded, the Meteorological Service entered into the interwar period and struggled to reach an adequate level of operation until 1937 when the Service was dissolved and its assets absorbed into the Air Corps' own "Air Weather Service." Chronic personnel shortages were a symptom of two conditions. First, the amateur meteorological observer could no longer be called upon to share in weather data gathering duties. The amateur observer was excluded from the Meteorological Service primarily because the Service was a military organization and only enlisted men who received training in meteorology could perform the necessary work. The fact that the Signal Corps put the employees of the Meteorological

\footnotetext{
${ }^{81}$ Fuller, Thor's Legions, 17.

${ }^{82}$ Flammer, "Meteorology," 35
} 
Service through training reflects the increasing complexity of meteorological work. Gathering adequate weather data was relatively simple in 1900, adjusting and reading a barometer or operating a sling psychrometer for instance. But by the end of the First World War, a Meteorological Service observer was expected to operate a multitude of instruments - many of which, as shown previously, required sophisticated calculations and graphing to render useable results - and to possess a basic understanding of the various military applications of the weather data being gathered. ${ }^{83}$

Indeed, by the 1920s there was a marked division between the meteorological work done by Meteorological Service personnel and the amateur observer. In a short book titled Weather and Weather Instruments for the Amateur, Taylor Instrument Companies (the publisher) sought to simplify the reading of weather instruments and to help laymen forecast the weather. ${ }^{84}$ The book contains a multitude of tips, diagrams, charts, and definitions including: how to use a barometer, thermometer, and compass as well as a chapter on humidity's effect on health and a page of rhyming couplets titled "Weather Lore" ${ }^{85}$ Although an experienced amateur observer (or, perhaps more accurately, a hobbyist observer) could be trained relatively quickly to perform the more complex tasks of the Meteorological Service, the contents of the book show that the scope of amateur weather work was far exceeded by the Service's daily peacetime observational routine. For example, beyond a short section describing cloud types and general conditions preceding rain, there is no mention of the importance of upper air conditions in forecasting. This

\footnotetext{
${ }^{83}$ See section "Organization of the Meteorological Service" above.

${ }^{84}$ P. R Jameson, Weather and Weather Instruments for the Amateur (Rochester: Taylor Instrument Companies, 1923) 5.

${ }^{85}$ The couplets range from vague proclamations: "When the wind is in the East, 'Tis neither good for man or beast," to specific forecasts: "if hoar-frost comes on morning's twain, The third day surely will have rain." Jameson, Weather and Weather Instruments, 111.
} 
is because sounding these altitudes required highly specialized equipment and training beyond the means of an average amateur.

The second condition that contributed to shortages was that students and universities continued to show low interest in meteorology during and after the First World War. ${ }^{86}$ This low interest was due in part to the confused perception of meteorology as a loosely defined set of practices closely related to astronomy and climatology. The New Christian Herald's encyclopedia entry on meteorology is an illustration of one such muddled definition.

Meteorology, that branch of science which observes, registers, classifies, and compares the various and varying phenomena of our atmosphere. It remarks, at the same time, the connection of those phenomena with heavenly bodies, and with the solid and liquid materials of the earth, in reference to their reciprocal and combined influence in determining the character of different climates, and with the view of learning the meteoric history of every region of our globe, of ultimately investigating the laws of atmospheric change and the plan of meteoric action; the theory, in fact, of meteorological phenomena, on which depends essentially the fitness of the various portions of the earth's surface for the production of different vegetable and other substances, and for the support of animal life.

Birds and beasts are all more or less sensitive to coming changes in the weather, and by observation of their movements, sure warning of changes in the weather may be obtained ${ }^{87}$

This entry is worth quoting nearly in its entirety because it crafts an image of meteorology that professional meteorologists would have contested at the time of its publishing in 1919. For instance, the assertion that meteorology remarks on the connection between climates, the "heavenly bodies," and the non-gaseous materials of the earth does not align with the precise and structured work of enlisted Meteorological Service personnel. Furthermore, the last suggestion that weather changes may be forecast by simply observing the behavior of animals is almost comical considering the sophisticated infrastructure of interconnected observation stations that facilitated forecasting during the First World War. Yet the last clause still contains a degree of

\footnotetext{
${ }^{86}$ See section "A Historiography of American Meteorology and the First World War" above.

${ }^{87}$ The New World Encyclopedia, George J. Hagar ed. (1919), s.v. "Meteorology."
} 
truth in that the seasoned forecaster's wealth of experience and innate ability to synthesize weather data into a reputable report was essentially little different than observing the instinctual reactions of animals honed by evolution.

The misconceptions surrounding meteorological work that continued after the First World War were addressed by institutions like the Monthly Weather Review. This journal, published by the American Meteorological Society since 1872, tried to drum up interest and attention to meteorological research and the meteorological organizations that were suffering from personnel shortages. By publicizing the wartime activities of the Meteorological Service as well as its current meteorological research endeavors and the careers in the field of meteorology that it offered, these articles sought to spread awareness of the Service's role in the First World War and the future of the increasingly airborne modern world. ${ }^{88}$ These articles also reflect the internal pressures that brought changes to the purpose and activity of the Service during this period of shortage. These pressures simultaneously contributed to the exacerbation of the Service's operational limitations while increasing the relevance of the Service by bringing in new clients that were in need of meteorological support. I will examine two articles from this list that highlight this pressure for change and adaptation.

\footnotetext{
${ }^{88}$ Many articles were published in the Monthly Weather Review for this purpose that were meant to espouse the achievements of the government weather organizations including the Meteorological Service. Articles about the Weather Bureau: Willis Gregg, "Aerological Investigations of the Weather Bureau During the War," Monthly Weather Review 47 (1919): 205-10 and "The Weather Bureau and the War," Monthly Weather Review 45 (1917): 411-12. Articles about the Navy Aerological Service: Ruy Finch, "Meteorology in the Naval Aviation Service Overseas," Monthly Weather Review 47 (1919): 227-28 and Alexander McAdie, "The Work of the Aerographic Section of the Navy," Monthly Weather Review 47 (1919): 225-226. Articles about the Signal Corps Meteorological Service and its school: Millikan, "Scientific Aspects," 210-15; Squier, "Meteorological Service," 84-85; Sherry and Waterman, "Military Meteorology," 215-22; "The Signal Corps Meteorological Service, A.E.F.," Monthly Weather Review 47 (1919): 870-71; "Syllabus of Lectures," 298; Oliver Fassig, "A Signal Corps School of Meteorology," Monthly Weather Review 46 (1918): 560-62; Charles Brooks, "Collegiate Instruction in Meteorology," Monthly Weather Review 46 (1918): 555-60; Ball, "Meteorological Course," 85-87.
} 
General Squier, the Chief Signal officer who initiated the formation of the Meteorological Service in 1917, modified the list of purposes of the Service in his post-war article that described the Service for the interested readers of the Monthly Weather Review (previously discussed in "Formation of the Meteorological Service"). Notably, he replaced task "c" with: "[t]o undertake for the first time in history of the world the problems of mapping the upper-air currents over the United States, Atlantic, and western Europe in aid of aviation, and particularly with reference to trans-Atlantic flight." 89 This modification shows that Squier recognized that the work of the Meteorological Service was relevant to organizations that were interested in commercializing trans-Atlantic flight. Given the massive demobilization that occurred after the armistice and the steadily increasing financial troubles of the American government, this wider relevance would become more important to the Meteorological Service as a justification of its demand for increased funding priority. The dramatic tone of the first clause was also intended to attract attention to the pioneering activities happening in meteorological studies at the time. Trans-Atlantic flight was an especially popular subject that caught public attention with superstar pilots competing to set flight records. At the time of this article's publication (February 1919), groups of aviators from a number of nations were gearing up to win glory for their nation as well as the Daily Mail's reward of $£ 10,000$ for the first successful transatlantic flight completed under 72 hours. ${ }^{90}$ These ambitious flights required the close support of meteorological organizations to have any hope of success. Squier's reference to the Meteorological Service's pioneering upper air work and its link to facilitating trans-Atlantic

\footnotetext{
${ }^{89}$ Squier, "Meteorological Service," 84. For the original list of purposes see Annual Report, 347.

${ }^{90}$ Bates and Fuller, Weather Warriors, 27-29.
} 
flight was his attempt to attract attention to the Service from the population concerned with developing this new technological feat into a commercial endeavor.

Later in the article, Squier elaborated on how this upper air sounding was conducted. The Meteorological Service staffed 26 stations that were spread across the United States and conducted daily pilot balloon soundings up to 35,000 feet before reporting their data to Washington D.C. where upper air wind charts were compiled. ${ }^{91}$ The growing archive of upper air wind condition data was showing that $95 \%$ of winds above 10,000 feet are from west to east and are often in excess of $100 \mathrm{mph} .{ }^{92}$ This tendency was an important discovery for early long-range aviators because it disproved the theory that winds could be escaped at high enough altitudes and showed that the direction of travel determined one's ideal flight altitude. Squier's article highlights how the work of the Meteorological Service contributed to the exploration of the upper air and to the conception of the atmosphere as a layered, three-dimensional structure.

Although the Meteorological Service had established a functioning upper air sounding network in the United States during the war, soundings of upper air conditions over the Atlantic remained impossible. This forced meteorologists to rely on extrapolation and inference based on data from the United States and Europe to issue forecasts of upper air conditions over the Atlantic. In his article about the four scientific investigations of the Meteorological Service during the war, Robert Millikan — the head of the National Research Council during the wardescribed the long-range propaganda balloons engineered by the Service as well as the potential application of their altitude stabilization technology to regularly sound the upper air over the Atlantic. His article credits three servicemen with inventing an apparatus that counteracted the

\footnotetext{
${ }^{91}$ Squier, "Meteorological Service, 84; Millikan, "Scientific Aspects," 215.

92 Squier, "Meteorological Service," 84.
} 
natural diffusion of hydrogen from a pilot balloon by regularly expending liquid kerosene (which expands into a gas at low pressure) causing re-inflation and re-ascension until the kerosene supply is exhausted.$^{93}$ This simple technology had been shown to extend the range of a pilot balloon ten times to over 1,000 miles. Millikan's proposal was to apply this technology to a fleet of pilot balloons equipped with various auto-recording meteorological instruments that could be released in the United States or from boats in the Atlantic, travel across the Atlantic at predetermined altitudes, and finally land in Europe before being collected. ${ }^{94}$

This truly ambitious proposal, to be carried out with the Meteorological Service's equipment and personnel, would require an increase in government funding to pay for the huge numbers of balloons, meteorological instruments, and technicians needed to sustain this constant stream of trans-Atlantic sounding balloons. Millikan's idea also relied on an assumption of continuously cooperative diplomatic relations between the United States and wherever the pilot balloons finally landed or else no data could be received. The endeavor also could not rapidly gather and report the data collected which made this data of little value for forecasting. Despite these criticisms, both articles show that the Meteorological Service had contributed to the greater knowledge of the workings of the upper atmosphere and that the Service was not an entirely irrelevant organization in peacetime.

Millikan had already left the Meteorological Service at the time of his article's publication and, by 1922, his proposal had gone unheard and was forgotten. In the meantime, the Meteorological Service had continued to expand — totaling twenty-seven active stations-

\footnotetext{
${ }^{93}$ Millikan, "Scientific Aspects," 214; Millikan, Autobiography, 176-77.

${ }^{94}$ Millikan, "Scientific Aspects," 215.
} 
without receiving an accompanying increase in budget or personnel. ${ }^{95}$ This increase in total stations was in part to support the "model airway" experiment. "Model airways" were designed to help pilots fly regularly between major destinations along aerial routes that were well marked with ground-markers, lights, and a radio beam. The Meteorological Service supported these highways by providing local forecasts and emergency storm and fog warnings to aviators before and during their flight (via wireless radio). ${ }^{96}$ Here, the usefulness of the Meteorological Service was affirmed while, at the same time, the Service's severe shortages in manpower and funding were increased. The majority of the further expansions in the number of the Meteorological Service's stations and, in 1928, a token increase in enlisted meteorological personnel were made for the benefit of the growing Air Corps (formerly the Air Service) and its own increasing responsibilities. ${ }^{97}$ This reflects the overall theme of the previous two articles, that is, that the work of the Meteorological Service was becoming increasingly relevant to military and commercial aviation during peacetime as a source of regular condition forecasts. It also shows that the Meteorological Service was gradually becoming exclusively associated with the Air Corps.

\section{Failures, Shortcomings, and Dissolution}

By the 1930s, the Meteorological Service's struggle to provide support on an inadequate budget and manpower allotment was worsening and the quality of the support rendered was decreasing. The public was alerted to this struggle (and the animosity between the Air Corps and

\footnotetext{
95 Flammer, "Meteorology," 38.

96 Flammer, "Meteorology," 38; Bates and Fuller, Weather Warriors, 43.

${ }^{97}$ Flammer, "Meteorology," 40, eighteen of the twenty-five stations in 1925 were used by the Air Service.
} 
the "old-guard" of the General Staff) after the fiasco of 1934 when President Franklin Roosevelt ordered the Air Corps to temporarily fly the air mail while new private contracts could be negotiated. Since these flights would need meteorological support, the Meteorological Service was also mobilized to aid the Air Corps. According to an Air Force study compiled about a decade later, only 2,028 out of 3,140 (65.8\%) scheduled air mail flights were completed by the Air Service - dismal performance largely the result of poor weather forecasts provided by the Meteorological Service. ${ }^{98}$ This debacle occurred after both the Meteorological Service and the Air Corps had been struggling for more than a decade to secure more resources and respect from the General Staff and set off the debate to solve the problems of these two disparaging branches of the armed forces.

There were a range of solutions proposed for the interrelated problems of the Meteorological Service and Air Corps. The Air Corps' primary demand was to become an independent branch of the military while the Signal Corps wished to either drastically reorganize and reinforce the Meteorological Service or simply be removed from the responsibility of administering it. After three years of investigations, debates, and bickering, it was suggested that — as the primary user of meteorological support — the Air Corps should take over the provision of its own meteorological service and that the Signal Corps Meteorological Service should be disbanded. ${ }^{99}$ On July 1, 1937, the assets and personnel of the Meteorological Service were transferred to the Air Corps and the Signal Corps officially "went out of the weather business" once again. ${ }^{100}$

\footnotetext{
98 This report is summarized in Flammer, "Meteorology," 51.

${ }^{99}$ Bates and Fuller, Weather Warriors, 46.

${ }^{100}$ Flammer, "Meteorology," 69.
} 


\section{Conclusion}

The empirical practices of meteorology were mobilized by the U.S. armed forces in 1917 to provide support mainly (but not exclusively) for aerial, chemical, and artillery operations. Support was given by the Signal Corps Meteorological Service mostly in the form of forecasts and reports on current local weather conditions. Given the urgency of mobilization in 1917, the formation and deployment of the Meteorological Service was a hurried and complicated affair. The stress of the task to provide the best possible results as fast as possible drove innovation within the Service. For instance, the Meteorological Service improved the pilot balloon upper-air sounding process by researching balloon ascent rates and compiling standard ascent tables from the results to eliminate the need for two theodolites and a surveyed baseline. Improvements and standardizations in meteorological practice — necessitated by the practice's military application during the First World War-helped solidify meteorology's role in the military as an aid to new technologies as well as general wartime operations. The fact that the Meteorological Service was not demilitarized or disbanded in 1918 and 1937 when its continuation came into question is a sign of this solidification.

These developments in meteorological practice also highlighted its foundational limits in the accuracy, scalability, and mobility of its applications. Professional meteorologists in America as well as Great Britain and elsewhere had recognized these limits before the strain of total war emphasized them further. What had changed by the end of the First World War was the increased demand coming from the military for more accurate forecasts and other meteorological work. The empirical forecasting methods of the nineteenth century were no longer "good enough" for the primary users of meteorological services. By the Second World War, these limits were beginning to be addressed as a meteorological science grounded in physical principles and 
aided by new data gathering instruments and increased funding gained prominence in the academic research environment.

Lacking its well-publicized role in dramatic events like D-Day, meteorology in the First World War is often overshadowed by its application in the Second World War. This trend is reflected in most modern scholarship on the history of meteorology. Often, this scholarship falls short of emphasizing the extent to which meteorological practice was integrated into the military and the functioning of its technologies and weapon systems. I see this wide integration as a potential unifying theme to a larger survey work on the First World War that touches on other applications of previously non-militarized sciences like chemistry and acoustics. 


\section{Works Cited}

Annual Report of the Chief Signal Officer to the Secretary of War, 1919. Washington: Government Printing Office, 1919.

Ball, Homer. "Meteorological Course Given in the Signal Corps School at Camp Vail, N. J., During 1920." Monthly Weather Review 49 (1921): 85-87.

Bateman, Harry. "Mathematical Theory of Sound Ranging.” Monthly Weather Review 46 (1918): 4-11.

Bates, Charles, and John Fuller. America's Weather Warriors, 1814-1985. College Station: Texas A\&M University Press, 1986.

Blair, William. "The Exploration of the Upper Air by Means of Kites and Balloons." Proceedings of the American Philosophical Society 48 (1909): 8-33.

Blair, William. "Meteorology for Aviation." Proceedings of the American Philosophical Society 67 (1928): 287-96.

Brooks, Charles. "Collegiate Instruction in Meteorology." Monthly Weather Review 46 (1918): 555-60.

Brooks, Charles. "General Extent of Collegiate Instruction in Meteorology and Climatology in the United States.” Monthly Weather Review 47 (1919): 169-70.

Burgess, George. “Applications of Science to Warfare in France.” The Scientific Monthly 5 (1917): 289-97.

Cave, C. J. P. "Some Notes on Meteorology in War Time." Quarterly Journal of the Meteorological Society 47 (1921): 7-10.

Douglas, C. K. M. "The Evolution of $20^{\text {th }}$-Century Forecasting in the British Isles." Quarterly Journal of the Royal Meteorological Society 78 (1952): 1-21.

Fassig, Oliver. “A Signal Corps School of Meteorology.” Monthly Weather Review 46 (1918): 560-62.

Finch, Ruy. "Meteorology in the Naval Aviation Service Overseas." Monthly Weather Review 47 (1919): 227-28.

Flammer, Philip. "Meteorology in the United States Army: 1917-1935." MA thesis, George Washington University, 1958.

Fleming, James Rodger. Meteorology in America, 1800-1870. Baltimore: Johns Hopkins University Press, 1990. 
Friedman, Robert. Appropriating the Weather: Vilhelm Bjerknes and the Construction of a Modern Meteorology. Ithaca: Cornell University Press, 1989.

Fuller, John F. Thor's Legions: Weather Support to the U.S. Air Force and Army: 1937-1987. Boston: American Meteorological Society, 1990.

Gregg, Willis. “Aerological Investigations of the Weather Bureau During the War.” Monthly Weather Review 47 (1919): 205-210.

Haber, Ludwig F. The Poisonous Cloud: Chemical Warfare in the First World War. Oxford: Clarendon Press, 1986.

Harper, Kristine. "Boundaries of Research: Civilian Leadership, Military Funding, and the International Network Surrounding the Development of Numerical Weather Prediction in the United States." PhD diss., Oregon State University, 2003.

Harper, Kristine. "Meteorology's Struggle for Professional Recognition in the USA (19001950).” Annals of Science 63 (2006): 179-99.

Harper, Kristine. Weather and Climate: Decade by Decade. New York: Facts On File, 2007.

Harper, Kristine. Weather by the Numbers: The Genesis of Modern Meteorology. Cambridge: MIT Press, 2008.

Harrington, Mark. "Systematic Exploration of the Upper Air with Estimates of Cost." Monthly Weather Review 42 (1914): 619-21.

Heller, Charles. Chemical Warfare in World War I: The American Experience, 1917-1918. Fort Leavenworth: Combat Studies Institute, 1984.

Hughes, Patrick. A Century of Weather Service: A History of the Birth and Growth of the National Weather Service, 1870-1970. New York: Gordon and Breach, 1970.

Innes, John. Flash Spotters and Sound Rangers: How They Lived, Worked, and Fought in the Great War. London: George Allen \& Unwin, 1935.

Jameson, P. R. Weather and Weather Instruments for the Amateur. Rochester: Taylor Instrument Companies, 1923.

Jones, Simon. World War I Gas Warfare Tactics and Equipment. Oxford: Osprey Publishing, 2007.

Kevles, Daniel. The Physicists. New York: Alfred A. Knopf, Inc., 1977.

Lyons, H.G. "Meteorology During and After the War." Monthly Weather Review 47 (1919): 8183. 
McAdie, Alexander. "Meteorology and the National Welfare." The Scientific Monthly 6 (1918): 176-87.

McAdie, Alexander. "The Work of the Aerographic Section of the Navy." Monthly Weather Review 47 (1919): 225-26.

Meteorological Observer: Instructors' Guide to All Arms. Washington: Government Printing Office, 1925.

Millikan, Robert. The Autobiography of Robert A. Millikan. New York: Pretice-Hall, 1950.

Millikan, Robert. "Some Scientific Aspects of the Meteorological Work of the United States Army.” Monthly Weather Review 47 (1919): 210-15.

Nebeker, Frederik. Calculating the Weather: Meteorology in the $20^{\text {th }}$ Century. San Diego: Academic Press, 1995.

Notes on the Meteorologic Elements Affecting Artillery. Translated by the Army War College. Washington: Government Printing Office, 1917.

Palazzo, Albert. Seeking Victory on the Western Front: The British Army and Chemical Warfare in World War One. Lincoln: University of Nebraska Press, 2000.

Raines, Rebecca. Getting the Message Through: A Branch History of the U.S. Army Signal Corps. Washington: Center of Military History United States Army, 1996.

Reed, Richard. "The Development and Status of Modern Weather Prediction.” Bulletin of the American Meteorological Society 58 (1977): 390-99.

Reed, William. "Military Meteorology.” Geographical Review 12 (1922): 403-11.

Shaw, Napier. "Meteorology: The Society and Its Fellows." Quarterly Journal of the Royal Meteorological Society 45 (1919): 95-111.

Sherry, Bertram and Alan Waterman. "The Military Meteorological Service in the United States During the War." Monthly Weather Review 47 (1919): 215-22.

Signal Corps Field Manual, Vol. II. Washington: U.S. Government Printing Office, 1931.

Squier, George Owen. "Meteorological Service of the Army." Monthly Weather Review 47 (1919): 84.

Stoltzenberg, Dietrich. Fritz Haber: Chemist, Nobel Laureate, German, Jew. Philadelphia: Chemical Heritage Press, 2004. 
"Syllabus of Lectures on Meteorology Given in the Course in Aeronautical Engineering at the Massachusetts Institute of Technology in Cooperation with Harvard University." Monthly Weather Review 45 (1917): 298.

The German Army Handbook of 1918. London: Frontline Books, 2008.

The New World Encyclopedia. Edited by George J. Hagar. New York: The Christian Herald, 1919.

“The Signal Corps Meteorological Service, A.E.F.” Monthly Weather Review 47 (1919): 870-71.

“The Weather Bureau and the War." Monthly Weather Review 45 (1917): 411-12.

Valencius, Conevery, B., David Spanagel, Emily Pawley, Sara Sidstone Gronim, Paul Lucier. "Science in Early America: Print Culture and the Sciences of Territoriality." Journal of the Early Republic 36 (2016): 73-123.

Ward, Robert. "The European Winter and the War [part I of II]." Journal of Geography 13 (1915): 169-71.

Ward, Robert. "The European Winter and the War [part II of II]." Journal of Geography 13 (1915): 208-15.

Ward, Robert. "The Weather Factor in the Great War: III.” Journal of Geography 14 (1915): 7176.

Ward, Robert. "The Weather Factor in the Great War: Late Winter and Spring." Journal of Geography 13 (1915): 315-17.

Ward, Robert. "Weather Controls Over the Fighting During the Spring of 1918." The Scientific Monthly 7 (1918): 24-33.

Ward, Robert. "Weather Controls Over the Fighting During the Summer of 1918." The Scientific Monthly 7 (1918): 289-98.

Whitnah, Donald. A History of the United States Weather Bureau. Urbana: University of Illinois Press, 1961. 